\title{
Naseljavanje njemačkih protestantskih obitelji u Slavonsku vojnu krajinu krajem 18. i početkom 19. stoljeća
}

DOI: https://doi.org/10.11567/met.34.2.3 UDK: $314.15-026.49(497.54+497.544)^{\prime \prime} 17 / 18^{\prime \prime}$ 274:314.15-026.49](497.54+497.544)“17/18“" Izvorni znanstveni rad Primljeno: 29.11.2018. Prihvaćeno: 23.12.2018.

\section{Sanja Lazanin}

\author{
Odsjek za migracijska i demografska istraživanja, Institut za migracije i narodnosti, \\ Zagreb \\ Sanja.Lazanin@imin.hr
}

\section{SAŽETAK}

Odjeci reformacije u Vojnoj krajini na području Hrvatske u 16. stoljeću bili su slabi. U Karlovcu kao glavnoj utvrdi Hrvatske krajine nalazio se protestantski propovjednik koji se brinuo o malobrojnim pripadnicima evangeličke vjeroispovijesti koji su uglavnom dolazili iz redova časnika austrijsko-njemačkog podrijetla ili su bili pripadnici njemačkih vojnih posada. Imajući u vidu slabu zastupljenost vjeroispovijesti proizašlih iz reformacije na vojnokrajiškom području tijekom 16. i 17. stoljeća, autorica se u radu usredotočuje na postupnu promjenu te situacije krajem 18. i u 19. stoljeću u novonastalim dijelovima Vojne krajine, od Slavonije preko Banata do Erdelja. Na tom području, koje je nakon velikog rata s Osmanlijama krajem 17. stoljeća postalo dio proširene habsburške vojne zone, tijekom 18. stoljeća dolazi do velikih upravnih, demografskih, crkveno-konfesionalnih i gospodarskih promjena. Autoričino se istraživanje fokusira na migracije i plansko naseljavanje u slavonskosrijemskom dijelu Vojne krajine koje se provodilo radi održavanja funkcionalnosti vojnokrajiškog sustava. U okviru intenzivnih i brojnih migracija na području slavonsko-srijemskih pukovnija tijekom 18. i 19. stoljeća naseljavanje obitelji protestantskih vjeroispovijesti (angesiedlete accatholische Familien) bilo je uglavnom usmjereno prema srijemskom dijelu Vojne krajine, osobito na područje Petrovaradinske pukovnije. Kao što je pokazao C. B. Hietzinger u svojoj knjizi Statistik der Militärgränze (1817. - 1823.), broj pripadnika protestantske vjeroispovijesti na području Vojne krajine početkom 19. stoljeća bio je višestruko manji u usporedbi s prevladavajućim katoličkim i pravoslavnim stanovništvom. Uzimajući u obzir zakonski okvir i odredbe koje su regulirale naseljavanje protestanata $u$ Vojnu krajinu, $u$ radu se, na temelju izvornoga arhivskoga gradiva i usporedbom s već objavljenim podacima, prikazuju razlozi, okolnosti i tijek naseljavanja protestantskih obitelji, njihovo podrijetlo i uvjeti pod kojima su naseljavani. Pritom se opisuju njihove materijalne prilike u novoj sredini, mogućnosti obavljanja vjerskih obreda, odnos stanovništva većinskih vjeroispovijesti prema njima te njihove građanske i vjerske slobode u Slavonskoj vojnoj krajini.

KLJUČNE RIJEČI: protestantske obitelji, naseljavanje, Slavonsko-srijemska vojna krajina (granica), Nijemci, 18. i 19. stoljeće 


\section{UVOD}

U okviru procesa naseljavanja jugoistočnih dijelova Habsburške Monarhije - južne Ugarske, Bačke, Banata, Srijema i Slavonije - germanskim i slavenskim, pretežno katoličkim stanovništvom iz srednjoeuropskog prostora, koje je država organizirala i/ili nadzirala tijekom 18. i do polovine 19. stoljeća, naseljen je i veći broj protestantskih obitelji. Iako je njihov udio $\mathrm{u}$ ukupnome useljeničkom korpusu bio razmjerno malen, potomci te skupine, kao dio njemačke etničke zajednice, ostavili su značajan trag u ekonomskome, kulturnom i društvenom životu spomenutog područja - sve do današnjih dana. Već sama ta činjenica opravdava znanstveni interes za okolnosti njihova naseljavanja. ${ }^{1}$

Do naseljavanja protestanata na prostor Slavonsko-srijemske vojne krajine (granice) $)^{2}$ u 18. i početkom 19. stoljeća dolazilo je u iznimnim slučajevima, ali ti su slučajevi ipak zanimljivi, osobito u kontekstu istraživanja drugih migracijskih tokova koji su se odvijali na tom prostoru. Ako ništa drugo, ono što taj povijesno-demografski fenomen čini zanimljivim već je sama činjenica da je Habsburška Monarhija, kao zemlja izrazite katoličke orijentacije u unutarnjoj i vanjskoj politici, dopustila naseljavanje protestantskih obitelji u novouspostavljeno područje Vojne krajine. Osim toga s užega, nacionalnopovijesnog stajališta zanimljivo je i to da su na dio područja koje je

Tekst je nastao na temelju izlaganja »Naseljavanje protestanata u Slavonsko-srijemsku vojnu krajinu u 18. i 19. stoljeću« održanog na međunarodnome znanstvenom skupu Reformacija u Europi i njezini odjeci: Povodom 500. obljetnice Lutherovih teza (Osijek, 19. - 20. listopada 2017.).

2 U hrvatskoj historiografiji danas je izraz »Vojna krajina« postao uobičajen za pogranični prostor prema Osmanskom Carstvu koji se postupno formirao od 16. i održao do 19. stoljeća, a čiji se teritorijalni opseg i ustroj u tom razdoblju mijenjao, ovisno o vojnopolitičkim i socioekonomskim okolnostima. Za dio te vojne i upravne cjeline koji se početkom 18 . stoljeća počeo oblikovati na području Slavonije i Srijema uvriježen je izraz »Granica«, a za njezine stanovnike "graničari«. Radi jasnoće i terminološke dosljednosti za pojam koji se u izvorima javlja kao Militär Gränze, sa svim njegovim povijesno-geografskim varijacijama, u daljnjem se tekstu upotrebljava izraz »Vojna krajina«. Sukladno takvoj praksi, za slavonski i srijemski dio navedenog teritorija, koji se u izvorima javlja u različitim terminološkim inačicama (Slavonische/Slavonisch-syrmische Militär Gränze ili jednostavno Slavonische Grenze), upotrebljavaju se izrazi »Slavonska vojna krajina«, »Slavonsko-srijemska vojna krajina« $\mathrm{i}$ »Slavonska krajina«. Alternativno, na nekoliko mjesta gdje je to opravdano kontekstom za isti se prostor upotrebljava skraćenica »Granica«. Za dio Vojne krajine u Banatu upotrebljava se naziv »Njemačko-banatska vojna krajina « ili samo »Banatska krajina«. U skladu s time, ujednačena je i pridjevska upotreba toga pojma: dakle, »krajiški« i »vojnokrajiški«, premda je u Slavoniji uobičajen izraz "graničarski«, pa se iz tog razloga na odgovarajućim mjestima spominju »krajiške općine« (umjesto »graničarske općine «). Kada se pak želi referirati na stanovnike Slavonske (ili Banatske) vojne krajine upotrebljava se u tim krajevima povijesno uvriježeni naziv »graničari«, a za njihovu aktivnost pridjev "graničarski« (npr. "graničarska rabota«i sl.). 
oslobođeno u ratu s Osmanlijama krajem 17. i u prvoj polovini 18. stoljeća pravo polagali i hrvatski staleži putem Hrvatskog sabora kao staleškog tijela i nositelja državnopravnih tradicija Hrvatsko-slavonskoga Kraljevstva. Temeljem navedenog prava to je tijelo donijelo zakonske odredbe koje su bile u suprotnosti s odredbama Ugarskog sabora, a kojima se protestantima zabranjuje naseljavanje na području Hrvatsko-slavonskoga Kraljevstva (v. Šišić, 1975: 306; Kurelac i Ladić, 2005: 106; Heka, 2013: 1270-1271).

Imajući u vidu navedene okolnosti, u radu će se na temelju arhivskog materijala iz Hrvatskoga državnog arhiva istražiti razlozi, tijek i uvjeti naseljavanja protestantskih obitelji u područje Slavonske vojne krajine, s osobitom pozornošću prema njihovu podrijetlu, sociodemografskim obilježjima te odnosu vlasti i lokalnog stanovništva prema novopridošlim stanovnicima.

\section{DOSADAŠNJA ISTRAŽIVANJA}

Kad je riječ o dosadašnjim istraživanjima migracija u Vojnoj krajini, valja započeti s autorima iz 19. stoljeća koji su prvi prikupili i u maniri onodobnih shvaćanja i pisanja povijesti sintetizirali podatke o vojnokrajiškoj povijesti. S obzirom na njihovu relevantnost, a bez obzira na to što ti autori nisu bili profesionalni povjesničari, neka se njihova djela opravdano smatraju »neizostavnima«. Na prvome mjestu valja navesti četverosveščano djelo Franza Vaničeka Specialgeschichte der Militärgrenze aus Originalquellen und Quellenwerken geschöpft iz 1875. u kojemu autor, uz pregled povijesti cijele Vojne krajine, donosi i podatke o migracijama na tom području od 16. do 19. stoljeća. Budući da su autoru bili na raspolaganju izvorni dokumenti, podaci iz navedenog djela dobro su polazište za daljnja istraživanja. Problem za današnje istraživače je međutim to što njegov rad ne upućuje uvijek na sve izvore, a dokumenti na koje se poziva ne sadržavaju današnje signature (jer još nisu bili arhivirani prema današnjim pravilima), pa ih je teže identificirati. Nadalje, vrijedna su spomena dva starija rada statističko-opisnoga karaktera, knjiga J. A. Demiana Statistische Beschreibung der Militär-Gränze u dva sveska i knjiga Carla B. Hietzingera Statistik der Militärgränze des österreichischen Kaiserthums u tri sveska. Oba su djela objavljena početkom 19. stoljeća i pisana, kao i Vaničekovo, po narudžbi ili za potrebe državnih vlasti, što također valja uzeti u obzir pri evaluaciji njihovih zaključaka. Kad je riječ o suvremenoj historiografiji, kod autora različitih sinteza hrvatske ili vojnokrajiške povijesti naseljavanje Nijemaca na prostor jugoistočne Europe, a time i hrvatskih zemalja, u pravilu se spominje u kontekstu drugih 
migracija. Među istraživačima koji su se bavili poviješću njemačke etničke zajednice na području hrvatskih zemalja, a osobito njezinim stradanjima i deportacijama u 20. stoljeću, istaknuto je ime povjesničara Vladimira Geigera. U njegovoj knjizi Nijemci u Đakovu i Đakovštini (2001.) jedno se poglavlje po naseljavanju Nijemaca u taj kraj tijekom 18. i 19. stoljeća. Uz ostalo, autor donosi podatke o dotadašnjim istraživanjima migracija Nijemaca na prostoru Hrvatske i o njihovoj zastupljenosti u ukupnom stanovništvu. Isti autor u preglednom tekstu Nijemci u Hrvatskoj (1991.) sažeto prikazuje povijest te etničke zajednice na hrvatskom prostoru od srednjovjekovnog razdoblja do 20. stoljeća, uključujući osnovne pravce i valove njihova naseljavanja tijekom 18. i 19. stoljeća. Od recentnih djela njemačke provenijencije koja se bave naseljavanjem Nijemaca u Ugarsku i istočne dijelove Habsburške Monarhije valja istaknuti dva osobito relevantna za ovaj rad. Márta Fata objavila je 2014. godine monografiju Migration im kameralistischen Staat Josephs II. u kojoj daje iscrpnu analizu procesa naseljavanja Nijemaca u Ugarsku uspoređujući teorijske pretpostavke kojima su se rukovodile politike u doba prosvjetiteljstva s njihovom realizacijom u kameralistički orijentiranoj državi, pri čemu je osobito zanimljiv autoričin pokušaj da se fenomen onodobnih migracija razmotri iz perspektive privlačnosti destinacije. Knjiga Karl-Petera Kraussa Deutsche Auswanderer in Ungarn: Ansiedlung der Herrschaft Bóly im 18. Jahrhundert iz 2003. donosi analizu njemačkog naseljavanja privatnih vlastelinstava u Ugarskoj, konkretno Batthyányjeva vlastelinstva Boja. To je djelo važno za temu ovog rada jer prikazuje karakteristične obrasce migracijskih procesa u južnoj Transdanubiji i okvirne uvjete tih procesa.

Najužim dijelom ove teme bavio se Lazar Ćelap u radu »Kolonizacija Nemaca u današnjoj Vojvodini 1790-1792. godine« iz 1962., u kojemu prenosi sadržaje dokumenata Hrvatskoga državnog arhiva vezanih uz naseljavanje Nijemaca, uključujući one protestantske vjeroispovijesti.

Na kraju valja spomenuti tzv. zavičajne knjige (njem. Heimatbücher) koje pružaju zanimljive i korisne podatke o pojedinačnim slučajevima naseljavanja. ${ }^{3} \mathrm{U}$ njima autori, u pravilu bivši stanovnici pojedinih naselja u koja su u 18. i 19. stoljeću bili kolonizirani Nijemci, opisuju svoj stari zavičaj nakon što su iz njega protjerani poslije Drugoga svjetskog rata. Te knjige imaju

\footnotetext{
Na njemačkom govornom području objavljeno je više od trideset zavičajnih knjiga o Podunavskim Švabama u Hrvatskoj, a brojne su i one o toj etničkoj zajednici u drugim zemljama. Za temu ovoga rada tri su osobito relevantne: Heimatbuch der Deutschen aus Vinkovci und Umgebung (1975.) Valentina Oberkerscha, zatim Familien- und Sippenbuch Neudorf bei Vinkovci (1986.) Johanna Badera i Josefa Jakobera, te Heimatbuch Neu-Passua (1989.) Irmgard Hudjetz-Loeber. Prva je o Vinkovcima, druga o Novom Selu kraj Vinkovaca, a treća o Novoj Pazovi.
} 
karakter kronika i mješavina su osobnih sjećanja i povijesnih činjenica. U njima su obuhvaćene teme o doseljavanju, broju stanovnika u pojedinim razdobljima, davanju imena, crkvenom životu, narodnim običajima, lokalnom načinu gradnje kuća, anegdotama itd. Među autorima podrijetlom iz jugoistočne Europe valja spomenuti Valentina Oberkerscha koji je dao najcjelovitiji prikaz povijesti njemačke etničke skupine u Hrvatskoj, Slavoniji, Srijemu i Bosni u djelu Die Deutschen in Syrmien, Slawonien, Kroatien und Bosnien: Geschichte einer deutschen Volksgruppe in Südosteuropa (1989).

Kad je riječ o istraživanju reformacije i utjecaja koji je imala na hrvatskome povijesnom prostoru, valja izdvojiti monografiju Stanka Jambreka Reformacija u hrvatskim zemljama u europskom kontekstu iz 2013. u kojoj autor daje pregled povijesti reformacije $u$ Europi, uključujući pokušaje njezina širenja na hrvatske prostore iz perspektive društvene i kulturne povijesti. Djelo koje se bavi različitim aspektima reformacije i njezina utjecaja na hrvatski prostor jest zbornik radova The Reformation in the Croatian Historical Lands. Research Results, Challenges, Perspectives, koji su 2015. uredili Zrinka Blažević, Stanko Jambrek i Nataša Štefanec. Knjiga donosi autorske teksto$\mathrm{ve}^{4}$ od kojih se neki bave utjecajem reformacije u hrvatskim pograničnim krajevima.

\section{IZVORI, PRISTUP I TERMINOLOŠKE NAPOMENE}

Istraživanje za ovaj rad temelji se na pisanim povijesnim izvorima iz fonda Slavonske generalkomande (SGK) koji su pohranjeni u Hrvatskome državnom arhivu (HR-HDA) u Zagrebu. Taj fond sadržava različite dokumente nastale radom administracije generalkomande Slavonsko-srijemske vojne krajine koja je imala ulogu zemaljske vlade za to upravno vojno područje. Fond obuhvaća razdoblje od 1701. do 1848. i sastoji se od 162 kutije spisa i 126 knjiga. Među brojnim spisima različita sadržaja i namjene - od vojnih preko gospodarskih i graditeljskih do kulturno-vjerskih - nalazi se znatna količina izvora koji dokumentiraju naseljavanje stanovništva u Slavonsku vojnu krajinu. Spisi su razvrstani u dvije serije - opći spisi i prezidijalni spisi. Za razdoblje od sedamdesetih godina 18. stoljeća do četrdesetih godina 19. stoljeća sačuvano je oko pedeset kutija dokumenata općih spisa koji sadržavaju podatke o migracijama, između ostaloga i o doseljavanju i smještaju protestantskih obitelji na slavonsko vojnokrajiško područje. U ne-

Između tekstova u zborniku valja izdvojiti onaj N. Štefanec koji govori o prilagodljivoj vjerskoj politici obitelji Zrinski na njezinim imanjima za vrijeme reformacije, a koju su prilagođavali lokalnoj tradiciji i običajima (Štefanec, 2015). 
koliko kutija prezidijalnih spisa iz četrdesetih godina 19. stoljeća nalaze se dokumenti o zabrani naseljavanja protestanata u Slavonsku vojnu krajinu, o izgradnji crkava i osnivanju škola za protestantske vjernike te o pritiscima s kojima su se predstavnici te konfesije suočili u području Srijema.

Građa relevantna za doseljavanje i uređenje pojedinih pitanja iz života »nekatoličkih « obitelji doseljenih u Slavonsku krajinu isključivo je na njemačkom jeziku i pismu. Sastoji se uglavnom od dopisa Dvorskoga ratnog vijeća za Slavonsku generalkomandu ili za zapovjedništva Petrovaradinske, Brodske i Gradiške pukovnije te Šajkaškog bataljuna, odnosno istoimenih kantonskih zapovjedništava. Tu ulaze naredbe za glavno zapovjedništvo Petrovaradinske pukovnije, tablice s popisom osoba koje migriraju na područje Vojne krajine te nacrti i planovi za smještaj doseljenika.

Izvori upotrijebljeni za ovo istraživanje imaju svojih prednosti i ograničenja: s jedne strane, podaci u njima službeni su i pouzdani te pružaju uvid u perspektivu državnih i vojnih vlasti u čijoj se organizaciji i pod čijim se nadzorom naseljavanje provodilo; s druge pak strane, budući da ne nude nikakva izravna svjedočanstva samih migranata, ali ni lokalnog stanovništva, ti su izvori bitno ograničeni, što analizu fenomena u čitavoj njegovoj složenosti bitno otežava. Analiza koja slijedi fokusirat će se na odluke i planove državnih tijela vezane za naseljavanje protestantskih obitelji, kao i na provedbu tih odluka i planova. Povijesni pristup istraživanoj temi određen je metodološkim okvirom tipičnim za rad na izvornim dokumentima pisanim njemačkim jezikom i pismom, njihovu transliteraciju i analizu sadržaja.

$\mathrm{Na}$ kraju, potrebno je dati i neke terminološke napomene. Pripadnici konfesija proizišlih iz reformacije u pravilu se u pregledanim dokumentima označuju općenitim izrazom »nekatolički« odnosno »nekatoličke obitelji«, »nekatolički kolonisti iz Carstva (akatholische/accatholische Familien, acatholische Reichs-Colonisten). Taj se termin primjenjivao isključivo na pripadnike konfesionalnih denominacija proizašlih iz reformacije, i to kako na pripadnike evangeličke tako i na one reformirane vjeroispovijesti (kalvine). Ponekad se u dokumentima precizira vjeroispovijest te se navodi »evangelička/augsburška konfesija/vjeroispovijest/religija « i »pripadnici augsburške konfesije " (evangelischelaugsburgische Konfession/Glaubensbekenntnis/Religion, augspurgische Confessions-Verwandte) ili »reformirana/helvetska religija " (reformirte/helvetische Religion). Od četrdesetih godina 19. stoljeća u izvorima se za obitelji reformiranih denominacija javljaju izrazi "protestantske obitelji, protestanti« (protestantische Familien, Protestanten). 


\section{DEMOGRAFSKA KRETANJA U VOJNOJ KRAJINI KRAJEM 18. I POČETKOM 19.STOLJEĆA}

Vojna krajina kao teritorij u upravnom pogledu odvojen od Banske Hrvatske i Slavonije bila je pod izravnom upravom Beča, točnije Dvorskoga ratnog vijeća. U Vojnoj krajini o svim se važnim pitanjima iz različitih područja života odlučivalo na inicijativu i uz suglasnost, bilo eksplicitnu, bilo prešutnu, vojnih vlasti na različitim upravnim razinama. Centralizirana uprava koja je sredinom 18. stoljeća organizirana na cjelokupnom teritoriju Vojne krajine odražava vojno ustrojstvo tog područja čija je osnovna upravna i vojna jedinica postala pukovnija. Osim na ujednačivanje teritorijalnog ustroja na području cijele Vojne krajine, geopolitičke prilike sredinom 18. stoljeća utječu i na definiranje njezine nove funkcije. To je rezultiralo strukturnim promjenama u krajiškim društvima koje su provedene od 1745. do 1770. i koje su vodile prema njihovu socijalnom i ekonomskom ujednačivanju (Kaser, 1997/II: 7).

Teritorij Slavonske vojne krajine $\mathrm{u}$ teritorijalno-upravnom smislu zaokružen je sredinom 18. stoljeća kada je vojnokrajiški dio razdvojen od civilnog dijela (Provincijala), a obuhvaćao je pojas zemlje uz rijeku Savu, od rijeke Lonje, točnije od Kraljeve Velike i Lipovljana, do Zemuna. U vojnoupravnom pogledu ta se Granica sastojala od tri pješačke pukovnije: Gradiške, Brodske i Petrovaradinske, a od 1764. upravi Slavonsko-srijemske generalkomande podređen je i Šajkaški bataljon koji je obuhvaćao uski pojas od šest naselja uz Dunav na bačkoj strani, a namjena mu je bila održavanje »službe na vodi« (Vaniček, II/1875: 111-114). Ta centralizirana uprava provodila se preko glavnog zapovjedništva (generalkomande) koje je za Slavonsku krajinu do 1783. bilo u Osijeku. Tada je Slavonsko zapovjedništvo spojeno sa zapovjedništvom Banatske vojne krajine $u$ Temišvaru, pod nazivom »Slavonsko-banatska generalkomanda«, i premješteno je iz Osijeka u Petrovaradin. Dva se zapovjedništva ponovno razdvajaju 1792. (Vaniček, 1875/III: 77). Zapovjedništvo za Slavonsku krajinu, koje se u izvorima ponekad naziva i Slavonsko-srijemsko glavno zapovjedništvo, nakon razdvajanja od Banatskog zapovjedništva ostaje u Petrovaradinu. Od 1787. do 1800. u Vojnu je krajinu uvedeno kantonsko uređenje, u čijoj su nadležnosti bili civilni poslovi pukovnije, uključujući poslove vezane uz naseljavanje novog stanovništva.

Kao što su pokazala dosadašnja brojna povijesna istraživanja, demografski razvoj Hrvatsko-slavonske vojne krajine obilježen je migracijama. Najkonciznije rečeno, krajiško društvo nastaje od doseljeničkih obitelji (v. 
Kaser, 1997/II: 43). Slavonska vojna krajina postupno se oblikuje od početka 18. stoljeća naseljavanjem stanovništva koje je, uz razmjerno mali broj starosjedilaca (kako se može zaključiti iz izvora), činilo demografsku osnovu za formiranje vojnokrajiškog sustava na tom prostoru.

\section{Poticaji za doseljavanje u Slavonsku vojnu krajinu u 18. stoljeću}

Na područje Slavonsko-srijemske vojne krajine doseljava se stanovništvo iz različitih područja: iz starih dijelova Vojne krajine kao što je Karlovački generalat, iz hrvatskih područja pod mletačkom vlašću, zatim kršćansko stanovništvo s teritorija pod osmanskom vlašću te stanovništvo iz drugih dijelova Habsburške Monarhije i Svetoga Rimskog Carstava. Uzroci preseljenja bili su različiti. ${ }^{5}$ Među brojnim potisnim čimbenicima najvažnije mjesto zauzima loša ekonomska situacija u područjima iz kojih se stanovništvo iseljavalo, a čije su posljedice bile glad, opća nestašica i nedostatak životnog prostora (prenapučenost) s obzirom na prirodne resurse, kao što je primjerice bio slučaj u Karlovačkom generalatu početkom i sredinom 18. stoljeća (Kaser, 1997/I: 151-157). Prema austrijskom statističaru s početka 19. stoljeća Carlu B. Hietzingeru, prenapučenost pojedinih zemalja u okviru Monarhije i Svetoga Rimskog Carstva bila je jedan od ključnih uzročnih čimbenika preseljenja dijela stanovništva iz navedenih dijelova u slabije naseljene novoosvojene krajeve Habsburške Monarhije, uključujući Slavonsku vojnu krajinu (Hietzinger, 1817/I: 184-185). Daljnji poticaji useljavanja u vojnokrajiško područje, osobito s osmanskog teritorija, bili su ratna stradanja, strah od odmazde i želja za oslobođenjem od osmanske vlasti. O tomu svjedoče i najpoznatiji primjeri masovnih preseljenja katolika iz područja oko Sarajeva koji, nakon vojnog pohoda Eugena Savojskog 1697., prelaze na habsburški teritorij, ali i dva velika vala seobe pravoslavnoga srpskog stanovništva - prvi 1690. pod vodstvom patrijarha Arsenija III. Crnojevića, a drugi 1740. pod vodstvom Arsenija IV. Jovanovića (v. Šišić, 1975: 349; Ćirković, 2008: 175-176 i 182-183; Heršak, 1993: 257-258). Kako su pokazala dosadašnja istraživanja (Kaser, 1997), glavni motivacijski čimbenici dolaska stanovništva na područje Slavonske vojne krajine bili su razmjerno mala gustoća naseljenosti imigracijske destinacije, dostupnost velikih zemljišnih površina za obradu (u usporedbi s onima u dotadašnjemu mjestu boravka) na toj destinaciji, mogućnost dobivanja državne potpore za tu obradu te općenito bolji društveno-ekonomski uvjeti od onih na teritoriju pod civilnom upravom.

O uzrocima i pravcima iseljavanja iz srednje Europe u 18. i 19. stoljeću opširnije u: Bade (2003: 2-3); Oltmer (2017: 48-50). 
Dok su se u starim dijelovima Vojne krajine obitelji koje su naseljavane izborile za svoj status, $u$ novoformiranoj Slavonskoj krajini naseljavane obitelji nisu imale jamstvo da će dobiti status graničara, iako se nisu protivile ni statusu običnih podanika. Tek ustupanjem teritorija uz Savu vojnim vlastima Dvorska komora stvorila je preduvjete za dodjelu zemlje novodoseljenim obiteljima kao ekvivalent za vojnu službu. Stoga vojne vlasti nisu očekivale da će se novodoseljeno stanovništvo opirati poreznom opterećivanju njihova zemljišnog posjeda te su nastojale primijeniti model samofinanciranja slavonskoga vojnokrajiškog područja - model koji je mogao biti održiv samo ako se krajiškim obiteljima nametnula obveza plaćanja poreza (Kaser, 1997/I: 221-222; Hietzinger, 1817/I: 29-30). Najveći dio imigracije u Hrvatsko-slavonsku vojnu krajinu dogodio se do sredine 18. stoljeća, ali se taj proces nastavio i nakon tog razdoblja, osobito u Slavonskoj krajini, koja je sredinom 18. stoljeća bila još slabo naseljena i osiguravala dostatne zemljišne površine za nove doseljenike. O tome svjedoče brojni izvori koji sadržavaju podatke o količini slobodnog zemljišta u pojedinim slavonskim pukovnijama i naseljavanju nenaseljenih područja. Od 1776. do 1785. iz osmanskog i mletačko-dalmatinskog prostora dolazi preko četiristo obitelji (tj. ukupno, prema procjeni, oko 4000 stanovnika), od kojih je najveći broj naseljen u Petrovaradinskoj pukovniji. Sljedeći val naseljavanja dogodio se za vrijeme Austrijsko-turskog rata, od 1788. do 1791., kada se s područja pod osmanskom kontrolom doseljava gotovo devetsto obitelji, ponovno najveći broj njih na područje Petrovaradinske pukovnije (Kaser, 1997/II: 43-44).

\section{Demografski pokazatelji naseljenosti Slavonske vojne krajine}

Osim migracijskih procesa i prirodnog prirasta na demografsko stanje u Vojnoj krajini utjecali su i ratni pohodi u kojima je sudjelovala Habsburška Monarhija, osobito krajem 18. i početkom 19. stoljeća. Naime, unatoč doseljavanju, na tom je području dolazilo do stagnacije ili smanjenja broja stanovnika. Tek od 1815. područje cijele Hrvatsko-slavonske vojne krajine bilježi izraženiji porast broja stanovnika. U Slavonskoj krajini dolazi do znatnijega demografskog oporavka sedamdesetih godina 18. stoljeća, i to velikim dijelom zahvaljujući doseljavanju. Primjerice od 1771. do 1776. broj stanovnika, ne računajući vojne komunitete, porastao je za gotovo 40.000, točnije sa 135.000 na 174.000 (Hietzinger, 1817/I: 170; Kaser, 1997/II: 48). Od Austrijsko-turskog rata počinje suprotan proces. Premda se od 1776. do 1791. na slavonski vojnokrajiški teritorij doselilo oko 12.000 ljudi, broj stanovnika je 1802. pao na oko 173.000 , što se može pripisati intenzivnim ratnim aktivnostima Monarhije u kojima su sudjelovale vojnokrajiške trupe. 
Do 1813. broj stanovnika porastao je na 196.000, da bi 1815. ponovno došlo do njegova smanjenja. Godine 1825. prelazi 206.000 i uz varijacije od nekoliko tisuća ostaje na toj razini do sredine 19. stoljeća, kada je, prema popisu iz 1859., u Slavonskoj vojnoj krajini živjelo oko 203.000 stanovnika (Demian, 1807/II: 29-30; Kaser, 1997/II: 48-49).

U Slavonsku vojnu krajinu doseljava se i stanovništvo iz srednje Europe, iako u znatno manjem opsegu nego u Njemačko-banatsku krajinu, i to ponajviše ono njemačke, slovačke i češke etničke pripadnosti (Vaniček, 1875/ III: 64-68), o čemu svjedoče i brojni arhivski izvori. Među tim njemačkim i slovačkim obiteljima koje su naseljavane krajem 18. i početkom 19. stoljeća na područje Slavonske vojne krajine zastupljene su i protestantske obitelji, iako s razmjerno malim udjelom. Kako je došlo do naseljavanja protestanata u navedeno područje i koji su uvjeti to omogućili, prikazat će se na temelju analize podataka iz arhivskih izvora.

\section{ZAKONSKI PREDUVJETI ZA NASELJAVANJE PROTESTANATA U SLAVONSKU VOJNU KRAJINU}

Na adresu Slavonske generalkomande u Osijeku stigla je 12. ožujka 1779. jedna od brojnih carskih preporuka da se u Slavonsku krajinu naseljava marljive obrtnike i ratare s ciljem da sami sebi osiguraju egzistenciju i tako poboljšaju stanje poduzetništva (Industrie), ali i gospodarstva u cjelini, što će, kako se pretpostavljalo, izravno utjecati na povećanje vojnokrajiške populacije (HR-HDA, 430-SGK, Opći spisi, kut. 16, 1779-66-17). Od osamdesetih do devedesetih godina 18. stoljeća veći valovi naseljavanja zahvatili su Slavonsku vojnu krajinu. Doseljavao se velik broj kršćana iz raznih krajeva, ponajviše s osmanskog teritorija, pa je dio doseljenika morao biti upućen u civilni dio Slavonije (Provincijal). Naseljavanje se odvijalo pod nadzorom, a za taj su se proces iz državne blagajne izdvajala znatna novčana sredstva. Na temelju izvještaja Slavonsko-banatske generalkomande u Petrovaradinu može se zaključiti da je za potrebe kolonizacije 1787. najviše sredstava izdvojeno u Njemačko-banatskoj pukovniji, 15.000 f. (guldena) godišnje, zatim u Petrovaradinskoj pješačkoj pukovniji, 10.000 f., te u Brodskoj, Gradiškoj i Vlaško-ilirskoj pukovniji po 1000 f. (Vaniček, 1875/III: 64).

Od početka vojnokrajiškog sustava u 16. stoljeću i naseljavanja tog područja prebjezima iz zemalja pod osmanskom vlašću, među kojima je bilo brojno vlaško pravoslavno stanovništvo, nastojale su habsburške vlasti urediti i vjersko pitanje. Premda su 1608. zaključci Hrvatsko-slavonskog sabora o isključivom priznanju katoličke vjere i zabrani naseljavanja protestanata 
unutar granica Hrvatske i Slavonije dobili kraljevu sankciju i proglašeni zakonom, vojnokrajiški zapovjednici naseljavali su i pravoslavno stanovništvo na imanja hrvatskog plemstva u krajevima izloženim osmanskim napadima (Roksandić, 2004: 55-58). Tako je pravoslavno stanovništvo na tom prostoru, usprkos nastojanjima da ih se privede crkvenoj uniji s Rimokatoličkom crkvom, nastavilo prakticirati vjeru u skladu s vlastitim pravilima i obredima. Osim toga car Leopold I. dodijelio je vjerske slobode i određenu autonomiju i pravoslavnom stanovništvu koje se pod vodstvom patrijarha Arsenija Crnojevića doselilo na područje Ugarske krajem 17. stoljeća. Reformacija se u Hrvatsko-slavonskoj vojnoj krajini nije proširila i nije našla odjeka. Krajišnici Karlovačkoga i Varaždinskoga generalata borili su se protiv širenja reformacije u unutrašnjoaustrijskim zemljama, a sudjelovali su i u Tridesetogodišnjem ratu na strani carskih katoličkih snaga. Malobrojnim protestantima koji su se naselili u vojnokrajiškom prostoru jamčena je, po istom načelu kao i pravoslavnom stanovništvu, zaštita ispovijedanja njihove vjere (Hietzinger, 1817/I: 246). Iako je općepoznato da su i prije Patenta o vjerskoj tolerancija Josipa II. iz 1781. u Ugarskoj i na području Vojne krajine živjeli pripadnici nekatoličkih konfesija, tim je zakonom, koji se odnosio na austrijske nasljedne zemlje, Ugarsku, Hrvatsku i Slavoniju, i pravoslavnim i protestantskim vjernicima zajamčeno slobodno prakticiranje vjere i utemeljenje crkvenih općina. ${ }^{6}$ Da je među obiteljima koje su sedamdesetih godina 18. stoljeća živjele na području Slavonske vojne krajine bilo i onih protestantske vjeroispovijesti, može se zaključiti iz dopisa Dvorskoga ratnog vijeća Generalkomandi u Osijeku od 24. kolovoza 1776. U tom se dopisu navodi da se broj takvih obitelji na prediju Pazova u Srijemu od prethodne godine povećao za jedanaest kuća, i to unatoč carskoj naredbi iz 1773. kojom se ograničava daljnje naseljavanje nekatolika na to dobro. Tom su se naredbom zabranjivali povećanje broja nekatoličkih obitelji te gradnja ili kupnja novih kuća za takve obitelji. Ako je nekatolička obitelj poželjela izgraditi novu kuću ili je kupiti od pripadnika svoje vjere, Generalkomanda je bila obvezna to prijaviti Dvorskome ratnom vijeću u Beču, koje je o tome trebalo donijeti konačnu odluku. Također se navodi da su prema popisu iz 1776. u jedanaest spomenutih kuća živjela 22 muškarca i 34 žene te da se od Petrovaradinske pukovnije za takvo stanje zahtijevalo objašnjenje. ${ }^{7}$

Latinski i njemački tekstovi Patenta o toleranciji za Ugarsko Kraljevstvo iz 1781. objavljeni su u izvorniku i prijevodu. Vidi: Roksandić (2004: 125-151).

O zabrani novog naseljavanja nekatoličkih evangeličkih obitelji (angesiedelte Augspurgische Confessions-Verwandten, die auf dem Praedio Passue angesiedelte accatholische Famillien) u Pazovu govori niz dokumenata u: HR-HDA, 430-SGK, Opći spisi, kut. 13, 1776-66-77; kut. 13, 1776-66-94; kut. 13, 1776-66-97; kut. 16, 1779-43-40. 
Za vrijeme vladanja Marije Terezije, a prije stupanja na prijestolje Josipa II. i izdavanja Patenta o vjerskoj toleranciji i Patenta o iseljavanju

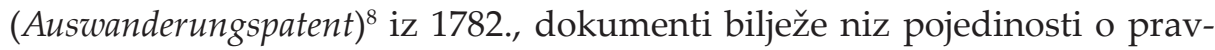
nom položaju nekatoličkih obitelji u Slavonskoj vojnoj krajini i o kontroli koju su nad njima prakticirale najviše vojne vlasti. Dopis iz 1779. iz Beča za Generalkomandu u Osijeku podsjeća da su još 1776. i 1777. izdane naredbe u cilju sprečavanja povećanja broja nekatoličkih obitelji u Pazovi i poduzimanju mjera za smanjenje njihova broja. U dopisu se upućuje prigovor vojnim vlastima u Slavonskoj krajini zbog okolnosti da se, unatoč navedenim naredbama, u prazne kuće doselilo pet pripadnika protestantske vjeroispovijesti koji su se u međuvremenu oženili i kojima je odobreno naseljavanje, umjesto da su u te ispražnjene kuće vlasti naselile katoličke ili pravoslavne obitelji. Isti dokument otkriva i mjere koje su bile predviđene za sprečavanje povećanja broja protestantskih stanovnika na području Slavonske vojne krajine. ${ }^{9}$ Nakon donošenja Patenta o vjerskoj toleranciji 1781. mijenja se i odnos prema naseljavanju protestantskih obitelji na područje Slavonske vojne krajine. Vjerske slobode i odnosi među pripadnicima različitih konfesija regulirani su različitim dodatnim uredbama. Tako je 1788. svim nasljednim zemljama upućeno nekoliko cirkularnih dopisa u kojima se govori o mogućnosti prelaska s nekatoličke na katoličku vjeru te se detaljno opisuju uvjeti razvoda braka nekatolika u slučajevima kada jedan od partnera prijeđe na katoličanstvo, kao i uvjeti sklapanja novoga braka (HR-HDA, 430-SGK, Opći spisi, kut. 27, 1788-21-241; 1788-21-252). Iako je Josip II. pod kraj života povukao brojne donesene zakone i uredbe u svrhu reformiranja Monarhije, Patent o vjerskoj toleranciji nije bio među njima. Tijekom devedesetih godina 18. stoljeća, u okviru nekoliko transporta dose-

8 Dok je Patent o naseljavanju (Ansiedlungspatent) Marije Terezije iz 1763. usmjerivao iseljenike najviše u Banat i Bačku i nije jednoznačno obećavao pomoć i oslobođenje od poreza doseljenicima, Patent o iseljavanju Josipa II. iz 1782. govorio je o »potpunoj slobodi savjesti i vjere« i predviđao obilne subvencije iseljenicima, što je omogućilo naseljavanje i siromašnih obitelji (Krauss, 2003: 33).

9 Iz Dvorskoga ratnog vijeća u Beču nalaže se Generalkomandi da ne dopusti ženidbu nijednome protestantskom seljačkom pomoćniku (Knecht) u Granici ni preseljenje sina protestanta u drugu protestantsku kuću koja je ostala ispražnjena s ciljem zasnivanja obitelji, a ako bi se nekatolički mladići naselili bez dopuštenja, ima ih se izbaciti iz Slavonije. Također se upozorava na opće načelo po kojemu za poduku u vjeronauku pripadnici svake konfesije imaju svoga dušobrižnika, dakle i protestanti i pravoslavci, dok je poduka u pisanju, čitanju i računanju jednaka za sve graničare. Stoga se zaključuje da u takvim uvjetima ni pripadnici pravoslavne ni evangeličke vjeroispovijesti u Pazovi ne trebaju vlastitu ili posebnu školu, nego je dovoljno zaposliti jednoga školskog učitelja za poduku, Nijemca katolika, kojeg će odobriti satnija, dok protestantskog učitelja valja otpustiti (HRHDA, 430-SGK, Opći spisi, kut. 16, 1779-43-40). 
ljenika iz Njemačkog Carstva ${ }^{10}$ koji su većim dijelom bili usmjereni prema Banatu, dolazi do naseljavanja protestantskih obitelji u srijemski dio Slavonske vojne krajine, u Petrovaradinsku pukovniju. Naseljavanja protestanata i njihova uključenost $\mathrm{u}$ vojne postrojbe na područje Vojne krajine bili su podložni stalnom preispitivanju i kritici, ponajprije od hrvatskog bana i Hrvatskog sabora, kao što se može zaključiti iz dopisa Dvorskoga ratnog vijeća koji potpisuje general Wallis, upućenog Slavonskoj generalkomandi u veljači 1792. (HR-HDA, 430-SGK, Opći spisi, kut. 32, 1792-66-38). U dopisu se argumentira da Vojna krajina ne potpada pod zakonske odredbe Ugarskog sabora i ugarskih staleža pa se stoga ni članak 26. Ugarskog sabora iz 1790. ${ }^{11}$, a kojim se ograničava pravo građanstva protestantima na području Hrvatskoga Kraljevstva, ne može odnositi na njezino područje. Wallis pritom upućuje na činjenicu da ne samo što nijedan zakonski propis ne sprečava naseljavanje nekatoličkih obitelji na područje Vojne krajine već se, naprotiv, i u spomenutome saborskom članku navodi da evangeličke obitelji koje žive u Donjoj Slavoniji smiju tamo ostati i zadržati svoje posjede te na njih primati pripadnike svoje vjere. Tridesetak godina poslije, 1819., veća skupina pripadnika evangeličke vjeroispovijesti naseljava se na području Slavonske vojne krajine u blizini Vinkovaca, a za njihov se smještaj osniva Novo Selo (Neudorf). Takva se praksa toleriranja naseljavanja protestanata mijenja carskom odlukom od 16. lipnja 1820. prema kojoj »u Hrvatskoj i Slavonskoj vojnoj krajini ne smije biti naseljena ni jedna obitelj koja ispovijeda evangeličku ili reformiranu religiju «, s time da oni koji su naseljeni prije tog datuma zadržavaju stečena prava (HR-HDA, 430-SGK, Opći spisi, kut. 87, 1829-Q-I-78). Dvorsko ratno vijeće u dopisu iz 1829., u kojemu upozorava na zabranu naseljavanja novih protestantskih obitelji iz 1820., skreće pozornost Slavonskoj generalkomandi da omogućivanje stjecanja majstorskog prava nekatoličkim naučnicima potiče naseljavanje protestanata i da je protivno carevoj odluci. Stoga se svakom kandidatu za majstorsko pravo

10 Kada se govori o mjestu podrijetla doseljenih njemačkih obitelji (abgeschickte Reichsfamilien, Reichs-Transmigranten), u tekstu se iz praktičnih razloga upotrebljava termin »Njemačko Carstvo« za prostor koji se do 1806. službeno naziva Sveto Rimsko Carstvo Njemačke Narodnosti.

11 Zakonski članak 26. o vjerskom pitanju osiguravao je prava protestantima na području Ugarske. To se pravo odnosilo na slobodno ispovijedanje vjere, održavanja službe Božje te vjersku poduku u školama. Pri zapošljavanju u državne službe vjerska pripadnost nije smjela igrati ulogu. No u točki 14. toga zakonskog članka naglašava se da u Hrvatskoj, Slavoniji i Dalmaciji ostaje na snazi tamošnji vjerski zakon po kojemu protestanti nemaju pravo na vlasništvo ni na obnašanje javne ili privatne službe. O Ugarskom saboru 1790., napucima hrvatskim zastupnicima i zaključcima koje je 1791. sankcionirao kralj Leopold II. opširnije u: Heka (2013: 1277-1280). 
nalaže da krsnim listom dokaže da ne pripada nekatoličkoj vjeroispovijesti, jer će mu se u protivnome to pravo uskratiti.

Broj pripadnika protestantskih konfesija na području Slavonske vojne krajine početkom 19. stoljeća bio je višestruko manji u usporedbi s prevladavajućim katoličkim i pravoslavnim stanovništvom. Prema podacima koje navodi Hietzinger pozivajući se na Demiana (pri čemu nije jasno na koju se godinu opisano stanje odnosi), u vojnoj je evidenciji bilo zavedeno 1330 muškaraca protestantske vjeroispovijesti. Riječ je uglavnom o evangeličkim doseljenicima njemačkog i slovačkog podrijetla, od kojih je većina bila naseljena u Staroj i Novoj Pazovi, Novim Banovcima i Mitrovici, dok je manji dio bio smješten u slobodnim vojnim komunitetima Zemunu, Petrovaradinu i Karlovcima. Usporedbe radi, prema Hietzingerovim je podacima bilo 55.819 muškaraca katolika i 52.555 pravoslavnih muškarca (Hietzinger, 1817/I: 248; Demian, 1807/II: 219). Franz Vaniček, koji se poslužio drugim sveskom Hietzingerove Statistike, navodi da je 1820. u Slavonskoj krajini živjelo 3880 protestantskih stanovnika, a u Njemačko-banatskoj krajini njih 6661 (Vaniček, 1875/IV: 253; Hietzinger, 1823/II-2: 457).

\section{PROCES NASELJAVANJA PROTESTANATA IZ NJEMAČKOG CARSTVA U SLAVONSKU VOJNU KRAJINU}

Naseljavanje iz Njemačkog Carstva i srednjoeuropskih dijelova Habsburške Monarhije u njezine jugoistočne krajeve odvijalo se organizirano i pod nadzorom središnjih vlasti u Beču i lokalnih civilnih i vojnih vlasti. Prema nekim autorima (Fata, 2014), za istraživanje uzroka migracija klasični model potisnih i privlačnih čimbenika kao ni koncept o prenapučenosti i slaboj naseljenosti nekog područja nisu dovoljni. M. Fata smatra da se u dosadašnjim istraživanjima habsburške politike naseljavanja u 18. stoljeću nedovoljno pozornosti poklanjalo prilikama u područjima doseljenja. Prema njoj, upravo je situacija u odredištu bila odlučujuća za donošenje odluke o migriranju (Fata, 2014: 31). Najveći broj njemačkih kolonista naseljavan je u podunavskom prostoru s težištem naseljavanja u Banatu, Bačkoj i Erdelju (Oltmer, 2017: 49). Tako su primjerice 1790. u Njemačko-banatsku krajinu naseljavani njemački kolonisti iz Elzasa, Lotaringije, Švapske, Württemberga i Badena koji su došli u čak tri transporta s ukupno 1921 osobom, među kojima je bilo i protestantskih obitelji. Kolonisti iz Rajnskoga kraja naseljavani su također u Njemačko-banatski kanton, ali i u Petrovaradinsku pukovniju (Vaniček, 1875/III: 65). 
Slavonska generalkomanda, koja je u to vrijeme bila nadležna i za Banat, te kantonske uprave Petrovaradinske i Banatske pukovnije dobivale su 1790. i 1791. ${ }^{12}$ iz Beča obavijesti o transportu njemačkih obitelji, uglavnom s područja Carstva, koje su Dunavom upućivane u Njemačko-banatsku krajinu i koje su prolazile kroz Petrovaradin, sjedište Generalkomande. Ti dopisi iz devedesetih godina 18. stoljeća vrijedni su pozornosti jer je uz neke od njih sačuvan i poimenični popis migranata. Dopisima se obavještava glavno vojno zapovjedništvo u Slavoniji ili pojedine kantonske uprave o prolasku migranata na putu za Banat kroz područje njihove nadležnosti. Tim se upravama nalaže da migrantima pruže pomoć u hrani i novcu, a da bečke vlasti izvijeste o raspoloživom smještaju u Banatskoj krajini.

Spomenuti se dopisi zapravo odnose na dva transporta koja su u proljeće 1790. krenula iz Njemačkog Carstva prema Banatu. O prvom transportu, koji je krenuo 15. ožujka 1790., u navedenim izvorima nema detaljnijih podataka. Drugi, koji je krenuo krajem ožujka ili početkom travnja 1790., sastojao se od četrdeset obitelji iz Carstva, točnije iz Elzasa i Švapske. Prema uputi iz Beča, valjalo je iz Slavonske krajiške blagajne za troškove uzdržavanja tih transporta isplatiti iznos od $142 \mathrm{f}$. $27 \mathrm{kr}$. koji je toj blagajni doznačio Ratni platni ured (Kriegszahlamt) iz Beča. ${ }^{13}$ Prema priloženome poimeničnom popisu migranata, u drugom je transportu ukupno bilo 157 osoba. Popis navodi broj obitelji, ime i prezime svakog migranta, spol, podrijetlo, dob, vjersku pripadnost, bračno stanje, zanimanje i napomenu u vezi s putnim ispravama. Prema popisu, taj se kontingent sastojao od 41 muškarca, 36 žena, 46 dječaka i 34 djevojčice. Prema vjerskom sastavu, najzastupljeniji su bili katolici, a bilo je i pet obitelji evangeličke vjeroispovijesti, dok je u jednoj obitelji otac bio evangelik, a majka i djeca katolici. ${ }^{14}$ U lipnju 1790. upućen je još jedan transport obitelji iz Njemačkog Carstva u Njemačko-banatski kanton. ${ }^{15}$ Taj je bio znatno veći i brojio je 742 osobe, a Bečki ratni platni ured osi-

12 O naseljavanju Nijemaca na područje današnje Vojvodine od 1790. do 1792. pisao je Lazar Ćelap, koji je u Zborniku Matice srpske iscrpno prikazao arhivske izvore o tome (Ćelap, 1962: 115-124).

13 O tome se govori u nekoliko dopisa s kraja ožujka i početkom travnja 1790. pod signaturom HR-HDA, 430-SGK, Opći spisi, kut. 29, 1790-10-30.

14 Tablica je datirana 7. travnja 1790. i naslovljena Aweiß derjenigen Leuten, welche von Elsaß, Zweybrücken etc. hieher emigrirt sind; und sich nach Hungarn begeben zu därfen wünschen (HRHDA, 430-SGK, Opći spisi, kut. 29, 1790-10-30).

15 Car Josip II. uveo je 1787. kantonalni sustav u Vojnu krajinu. Cilj je bio uspostavljanje civilnih upravnih organa na pukovnijskoj i nižim razinama te odvajanje od vojne uprave. Zadržano je pukovnijsko područje sa svojom upravom koja je bila nadležna za vojne poslove, a kantonska se uprava bavila isključivo civilnim pitanjima. Između brojnih poslova koji su bili u nadležnosti kantona, poput ubiranja poreza te brige o sigurnosti i ured- 
gurao je 668 f. 9 kr. novčane pomoći za njihov put. U popratnom dopisu iz Petrovaradina od 24. lipnja 1790. Banatskome kantonskom zapovjedništvu daju se preporuke o tome kako postupati prema migrantima da bi ih se zadržalo i nadziralo, jer je i Vojnoj krajini i državi stalo do toga da se useljenicima pruži sva potrebna pomoć kako bi se smjestili i prehranili preko zime. Pritom će se, kako stoji u dopisu, pokušati iskoristiti smještajne mogućnosti u drugim vojnokrajiškim kantonima i vojnim komunitetima (HR-HDA, 430-SGK, Opći spisi, kut. 30, 1790-66-75, Petrovaradin, 24. lipnja 1790.). U popisu migranata ili (kako ih sam izvor naziva) »transmigranata«, koji je sastavljen u Beču 12. lipnja 1790., nalaze se podaci o 132 obitelji sa 742 člana među kojima je 14 obitelji s 82 člana pripadalo evangeličkoj vjeroispovijesti (Consignation deren nach Peterwardein abgehenden Transmigranten, HR-HDA, 430-SGK, Opći spisi, kut. 30, 1790-66-75). Drugi dopis, upućen 28. lipnja 1790., a naslovljen na zapovijedajućega generala grofa Mittrowskoga, govori o problemima u koordinaciji između instancija koje su uključene u proces naseljavanja i o nedovoljnim smještajnim kapacitetima u Njemačko-banatskom kantonu. Navodi se da su na odredište pristigle 452 obitelji, premda je kantonska vlast dala informaciju da raspolaže s 390 praznih kuća, što je bilo u nerazmjeru s potrebama, osobito ako se uzmu u obzir migranti koji su tek trebali stići. Stoga se izražava bojazan da se ti ljudi neće moći smjestiti bez podizanja novih kuća, što bi bio dodatan trošak za državnu blagajnu. ${ }^{16}$

O lošim uvjetima za prihvat novih doseljenika iz Njemačkog Carstva koji su vladali u Njemačko-banatskoj krajini govori se i u nekoliko dopisa upućenih iz Beča Petrovaradinskome kantonskom zapovjedništvu i Slavonsko-banatskoj prijelaznoj generalkomandi. Napominje se da je iz Njemačkog Carstva u Njemačko-banatski kanton pristiglo više od četiristo obitelji, da je stanje sa smještajem loše te da su u pripremi još dva transporta s preko 1040 osoba, među kojima su i one evangeličke vjeroispovijesti koje se namjerava smjestiti u Pazovu, na području Slavonske vojne krajine. Budući da je Pazova bila opterećena ukonačivanjem konjaništva zbog rata $\mathrm{s}$ Osmanskim Carstvom, naglašava se da bi bila dobrodošla pomoć susjednih

nosti sela, kantonska uprava vodila je brigu i o odseljavanju i doseljavanju te se skrbila za siromašne i nezbrinute. Taj se sustav pokazao neodrživim zbog dva usporedna lanca zapovijedanja koja su često dolazila u sukob. Stoga je kantonalna uprava ukinuta 1800. i ponovno uspostavljena jedinstvena vojna uprava. Opširnije u: Vaniček (1875/III: 18-29); Kaser (1997/II: 20-21).

16 U dokumentu se govori o problemu smanjenja broja stanovnika u Banatskom kantonu, kao i o tome da je u prosincu 1789. na tom području bilo 13.000 osoba manje u usporedbi s 1786. godinom. Glavni uzrok pada broja stanovnika ne leži u odseljavanju obitelji, nego u smanjenju broja članova njemačkih obitelji, što nije bio slučaj sa srpskim i vlaškim obiteljima (HR-HDA, 430-SGK, Opći spisi, kut. 30, 1790-66-75, Petrovaradin, 28. lipnja 1790.). 
sela (Golubinaca, Vojke i Šimanovaca), premda bi Pazova, u kojoj već žive evangeličke obitelji, bila najprikladnija za smještaj tih doseljenika, od kojih bi se neki mogli smjestiti i u Mitrovicu (HR-HDA, 430-SGK, Opći spisi, kut. 30, 1790-66-82).

Što se tiče odabira lokacije za trajni smještaj njemačkih evangeličkih obitelji, zapovjednik u Mitrovici grof Mittrowsky predlagao je podizanje novih naselja u Petrovaradinskome kantonskom okrugu. Kao razlog za to naveo je nacionalni i vjerski žar koji je vladao u selima s domaćim vojnokrajiškim stanovništvom, zbog čega je predlagao da se Nijemce naseljava u zasebnim naseljima kako bi se izbjegao loš utjecaj domaćeg stanovništva na njih. Naime na pustari Tapavica, koja je bila u vlasništvu grofa Pejačevića, moglo se smjestiti šezdeset obitelji (s obzirom na raspoloživo zemljište), u Banovcima još deset, a iz okolnih se šuma mogla nabaviti građa za njihove kuće. Prednost Tapavice i Banovaca bila je i $\mathrm{u}$ tome što nisu bili daleko od Pazove (tj. Stare Pazove), u kojoj su živjeli Slovaci evangelici (HR-HDA, 430-SGK, Opći spisi, kut. 30, 1790-66-84). ${ }^{17}$ Prema sumarnom iskazu o broju doseljenih njemačkih obitelji u pojedine dijelove Vojne krajine, do srpnja 1790. ukupno su se doselilo 643 obitelji, od čega najviše u Njemačko-banatski kanton - njih 484, u Petrovaradinski kanton 62, a u Šajkaški 15. Od tri slobodna vojna komuniteta, u Zemun se naselilo 26 njemačkih obitelji, u Karlovce njih 36, a u Petrovaradin 20 (Sumarischer Ausweiß, HR-HDA, 430-SGK, Opći spisi, kut. 30, 1790-66-84). Krajem srpnja 1790. Dvorsko ratno vijeće obavještava vojne vlasti u Petrovaradinu da se zbog lošeg stanja Krajiškoga proventnog fonda i nedostatka sredstva ne može provesti planirano naseljavanje ni podizanje kuća na pustari Tapavica te da se naseljavanje odgađa za mirnija vremena. ${ }^{18}$ Takva odluka ne čudi s obzirom na ratno stanje u kojemu se Monarhija nalazila. Upravo je iz navedenog dopisa razvidna promjena u dotadašnjoj politici naseljavanja Josipa II. koja je omogućila preseljenje siromašnijim i slabije obrazovanim slojevima. Slavonsko-banatsku generalkomandu upozorava se da ubuduće izbjegava na područje Slavonske vojne krajine upućivati one

17 O doseljenju Slovaka evangeličke vjeroispovijesti sedamdesetih godina 18. stoljeća u (Staru) Pazovu vidjeti Gavrilović (1973: 63-68); Škiljan i Kralj Vukšić (2015: 23-24).

18 Zanimljiva su i daljnja objašnjenja i upute Dvorskoga ratnog vijeća o postupanju s doseljenicima. Njemačko-banatskome kantonskom zapovjedništvu nalaže se da se pobrine za doseljenike preko zime te da im se umjesto predviđenoga novčanog predujma od 6 guldena po obitelji pruži pomoć u naturi, ponajprije u alatu, što se opravdava time da su mnogi useljenici »neekonomični«, tj. da bi mogli neracionalno potrošiti novac. Dok se ne nađe smještaj za sve doseljenike, kako se navodi, valja im osigurati dobar privremeni smještaj, a ako se javi potreba za plaćenim privremenim radom u Vojnoj krajini ili u Srbiji, valja za to upotrijebiti doseljenike koji mogu raditi ili kao obrtnici ili kao zemljoradnici (HR-HDA, 430-SGK, Opći spisi, kut. 30, 1790-66-129). 
doseljenike koji se neće moći uzdržavati ni ratarstvom ni obrtom, već da prima samo one koji posjeduju dostatnu imovinu i kojima nije potrebna materijalna pomoć države za smještaj. Obitelji koje su bile predviđene za smještaj u srijemskoj Tapavici poslane su u kolovozu 1790. u banatsko Opovo, a Tapavica je ostavljena za nove doseljenike, za koje su se priželjkivali povoljniji uvjeti za naseljavanje i smještaj (HR-HDA, 430-SGK, Opći spisi, kut. 30, 1790-66-135).

Tijekom lipnja 1791. stigla je naredba iz Beča za Slavonsku generalkomandu u Petrovaradinu da se njemačke protestantske obitelji koje s ostalim doseljenicima stižu iz Carstva više ne šalje u Njemačko-banatsku pukovniju jer se tamo ne mogu prikladno smjestiti i ne može im se osigurati prikladno prakticiranje vjere. Stoga je Generalkomandi naloženo da te protestantske obitelji šalje u Slavoniju, na pustaru kod Pazove. Pri donošenju te odluke ključnu je ulogu odigrala povoljna okolnost da je u Pazovi postojala protestantska vjerska općina (HR-HDA, 430-SGK, Opći spisi, kut. 31, 1791-66116).

Dvije tablice donose imena obitelji koje su određene za naseljavanje $u$ Srijemu. Prvi popis sadržava imena članova jedanaest obitelji bez sredstava, od kojih deset evangeličkih i jedne reformirane (kalvinske). ${ }^{19}$ Riječ je o 63 osobe, među kojima je bilo četrnaest muškaraca, petnaest žena, šesnaest dječaka i osamnaest djevojčica. Drugi popis, datiran istim datumom kao prvi, sadržava imena osam evangeličkih obitelji s imovinom, ukupno 45 osoba, među kojima je bilo dvanaest muškaraca, deset žena, trinaest dječaka i deset djevojčica. ${ }^{20}$ Tih devetnaest protestantskih obitelji iz Njemačkog Carstva, uglavnom iz Württemberga, poslano je Dunavom prema Petrovaradinu kako bi se naselile na pustari Pazova. Od osam obitelji koje su sa sobom imale odgovarajuća novčana sredstva prikupljeno je 597 f. 45 kr. Taj je iznos pohranjen u Ratnome platnom uredu kako bi se mogao zajedno s potvrdom doznačiti Ratnoj blagajni u Petrovaradinu. Ta je mjera trebala poslužiti kao osiguranje od bijega migranata, odnosno kao jamstvo da će se oni naseliti prema planu. Novac im je trebao biti vraćen tek nakon što stignu u Pazovu i nakon što se vlasti uvjere da su se doseljenici tamo stvarno i smjestili. No početkom rujna 1791. austrijski zapovjednik u Srbiji grof Wallis zatražio je da se na pustari Tapavica, umjesto protestantskih, naseli osamdeset srpskih

19 Popis migranata Consignation über nachbenante zur Ansiedlung nach Peterwardein abgehende unbemittelte Akatholische Transmigranten, datiran je u Beču, 10. srpnja 1791. (HR-HDA, 430 SGK, Opći spisi, kut. 31, 1791-66-128).

20 Drugi popis s istim nadnevkom naslovljen je Consignation über nachbenante zur Ansiedlung nach Peterwardein abgehende bemittelte Akatholische Transmigranten (HR-HDA, 430 SGK, Opći spisi, kut. 31, 1791-66-128). 
obitelji. U međuvremenu je broj protestantskih obitelji koje su trebale smještaj narastao na 24 te je Wallis predložio da se tim obiteljima dodijeli zemlja koja je služila kao suvišpolje (Überland) uz cestu između Pazove i Batajnice, a na kojoj je bilo dovoljno mjesta za smještaj četrdeset obitelji. Osim toga kao prednost te lokacije Wallis je naveo mogućnost komunikacije s istovjercima u Pazovi. Generalkomanda je prihvatila njegovu sugestiju te uputila prijedlog Dvorskome ratnom vijeću da se umjesto na Tapavici novo selo za doseljene evangeličke obitelji podigne uz cestu između Pazove i Batajnice (HR-HDA, 430 SGK, Opći spisi, kut. 31, 1791-66-159; Ćelap, 1962: 122), što je Dvorsko ratno vijeće odobrilo.

S obzirom na to da su mogućnosti smještaja u Njemačko-banatskoj pukovniji u navedenom razdoblju bile vrlo ograničene, nastojalo se za nekatoličke obitelji iz Carstva koje nisu dobile smještaj u Banatu, pronaći smještaj $\mathrm{u}$ novoosnovanome mjestu pored Pazove, ponajprije iz vjerskih razloga. Tako je Slavonska generalkomanda u rujnu 1791. pozvala Banatsku generalkomandu da te obitelji pošalje u Srijem ili, riječima izvora, u Slavoniju. Budući da se kod Pazove planiralo podići četrdeset kuća, bilo je slobodnih mjesta za najviše šesnaest obitelji (HR-HDA, 430-SGK, Opći spisi, kut. 31, 1791-66-183; Ćelap, 1962: 122). Sljedeće godine u ožujku prijavilo se pet obitelji s petnaest muškaraca i sedamnaest žena iz Banata za naseljavanje u Novoj Pazovi. U to je vrijeme većina od četrdeset novopodignutih kuća već bila nastanjena (HR-HDA, 430-SGK, Opći spisi, kut. 32, 1792-66-50; Ćelap, 1962: 122). Sljedeći podatak koji pružaju izvori u vezi s naseljavanjem njemačkih obitelji iz 1792. spominje 58 obitelji iz Njemačkog Carstva u Novoj Pazovi i Novim Banovcima kojima je pružena materijalna pomoć kako bi se od njih napravilo »korisne zemljoradnike, privrednike i dobre graničare « (HRHDA, 430-SGK, Opći spisi, kut. 32, 1792-66-191). Već se 1820. broj evangeličkih njemačkih obitelji u Novoj Pazovi i Novim Banovcima udvostručio, točnije bilo ih je 117, što je bio dovoljno velik broj da se vlasti iz Beča uvjere u opravdanost zahtjeva novoosnovane zajednice za vlastitim dušobrižnikom (HR-HDA, 430-SGK, Opći spisi, kut. 67, 1820-Q-VIII-17).

Znatno većeg opsega od migracija iz Njemačkog Carstva i srednjoeuropskih dijelova Habsburške Monarhije u Slavonsku krajinu bile su one s osmanskog i mletačkog teritorija. Samo za vrijeme rata s Osmanlijama, 1788. - 1791., 564 migrantskih obitelji preselile su se na područje Petrovaradinskoga kantona. Kako se navodi u jednom dopisu za Dvorsko ratno vijeće i Kantonsko zapovjedništvo iz svibnja 1792., bilo je potrebno sagraditi još 370 kuća. Trošak za to iznosio je preko 2200 guldena, što je u velikoj mjeri opterećivalo Kantonsku proventnu blagajnu (HR-HDA, 430-SGK, Opći spi- 
si, kut. 32, 1729-66-82). Stoga je naseljavanje protestantskih obitelji činilo tek mali dio šireg procesa naseljavanja srijemskog dijela Slavonske vojne krajine.

Taj intenzivni proces naseljavanja rezultirao je time da, prema izvještaju upućenom iz Petrovaradina za Dvorsko ratno vijeće, 1801. više nije bilo mjesta za nove useljenike u Petrovaradinskoj pukovniji. Stoga je predloženo da se one koji budu stigli s osmanskog teritorija zaustavi u Zemunu, ali i da se obustavi prihvat daljnjih useljenika sve dok ne stigne informacija o mogućnosti naseljavanja Banata (HR-HDA, 430-SGK, Opći spisi, kut. 42, 180117-97). Kao što je razvidno iz dopisa Slavonske generalkomande upućenom Slavonskoj i Srijemskoj brigadi iz 1811., zajedno s novim useljenicima iz Ilirskih pokrajina pod francuskom upravom počeli su pristizati i oni iz turskog područja, što je bitno otežalo daljnje naseljavanje u Slavonskoj vojnoj krajini te natjeralo vlasti u Beču da počnu razmišljati o tome da imigrante preusmjeruju u Varaždinski generalat ili u banatski dio Vojne krajine (HRHDA, 430-SGK, Opći spisi, kut. 49, 1811-Q-11/29).

Dinamični demografski i migracijski procesi utjecali su na mogućnosti novog naseljavanja, koje su u prvom redu ovisile o raspoloživoj zemlji. Tako je 1819. transport Nijemaca iz Württemberga krenuo u Južnu Rusiju, ali je dio iseljenika u Vukovaru odustao od daljnjeg puta, pa su ih vlasti Brodske pukovnije bile prisiljene smjestiti na slobodnom zemljištu zapadno od Vinkovaca. Za naseljavanje u šumi pored Vinkovaca, čijim je krčenjem stvoreno zemljište za kuće i polja, odlučilo se četrdeset evangeličkih obitelji iz navedenog transporta (Schreckeis, 1983: 14).

\section{Socijalna struktura protestantskih doseljenika na temelju dvaju popisa migranata iz srpnja 1791.}

Premda u izvorima ne postoje sačuvani osobni podaci za sve one koje je država organizirano naselila, transporti doseljenika iz Njemačkog Carstva i Ugarske prema Banatu početkom devedesetih godina 18. stoljeća, koji su dijelom upućivani u Srijem i Slavoniju i koji su prolazili kroz Petrovaradin, mogu se analizirati na temelju sačuvanih popisa u fondu Slavonske generalkomande. Od šest sačuvanih popisa za 1790. i 1791. godinu, dvije tablice s popisom doseljenika iz srpnja 1791. važan su izvor demografskih i socioekonomskih podataka o evangeličkim doseljenicima koji su određeni za naseljavanje na pustari kraj Pazove. Riječ je o popisu od 10. srpnja 1791. koji je podijeljen u dva dijela (HR-HDA, 430-SGK, Opći spisi, kut. 31, 1791-66-128). Jedna tablica sadržava popis jedanaest protestantskih obitelji s ukupno 63 člana koje su bez novčanih ili materijalnih sredstava krenule 
prema Petrovaradinu radi naseljavanja u Srijemu. Druga sadržava popis osam obitelji s ukupno 45 članova koje su raspolagale određenim novčanim sredstvima. Na temelju podataka iz tablica mogu se analizirati dobni i spolni sastav doseljenika, njihov bračni status, zanimanje, mjesto podrijetla te njihova imovinsko-pravna situacija, i to s osobitim obzirom na mjesto podrijetla. Sve su te obitelji bile protestantske, točnije evangeličke, osim jedne reformirane. Podrijetlom su bile iz različitih mjesta iz vojvodstva Württemberg. Dob muškaraca - glavâ obitelji - kretala se od 24 do 50 godina, dok su žene, njihove supruge, bile u dobi od 25 do 64 godine. Od devetnaest popisanih obitelji jedna je bila samačka - riječ je o muškarcu čija su žena i sluškinja ostale na gospodarstvu u mjestu podrijetla, a jedan je bračni par bio bez djece. Jednom je bračnom paru u popisu obitelji pridružen odrasli muškarac čiji su supruga i djeca namjeravali naknadno mu se pridružiti, a jednu je obitelj činila udovica s četvero djece. Obitelji s maloljetnom djecom imale su od jednog djeteta do najviše petero djece. Najbrojnije su bile obitelji s četvero djece - njih sedam. Četiri su obitelji imale po petero djece, tri po dvoje djece, dvije po troje i dvije po jedno dijete. Što se tiče pridruženih članova obitelji, osim punice i odrasle braće, zabilježeni su sluge i sluškinje (u pet slučajeva). Od muških sluga (Knecht), dvojica su bila oženjena, a jedan neoženjen; od sluškinja, jedna je bila neudana, a jedna je imala dijete.

Što se tiče zanimanja odraslih muškaraca, evidentirano je osamnaest ratara, dva zidara, jedan tesar i jedan postolar. Iz napomena koje su navedene uz ime svake obitelji može se saznati da je među obiteljima bez sredstava većina njih trebala naslijediti imanje ili novčana sredstva ili ta sredstva priskrbiti prodajom imanja (u mjestu podrijetla) ili povratom potraživanja od drugih osoba. Napomene zabilježene uz popis osam obitelji koje su se $\mathrm{s}$ novčanim sredstvima uputile prema Petrovaradinu uglavnom se odnose na putne isprave i dopusnice nadležnih vlasti za iseljavanje. Osim toga uz ime svake obitelji navedena su i novčana sredstva kojima raspolažu, a koja su se kretala od 30 do 257 guldena, dok je ukupni iznos koji su obitelji s imovinom položile iznosio $597 \mathrm{f}$. $45 \mathrm{kr}$. Upravo se na primjeru odabira i naseljavanja protestantskih obitelji najbolje vidi provedba odluke vojnih vlasti da se zbog manjka sredstava za uzdržavanje imigranta naseljavaju one obitelji koje će imati početni kapital i koje neće ovisiti samo o pomoći države.

Zabilježeni sastav većine doseljeničkih obitelji upućuje na to da je riječ o jednostavnim nuklearnim obiteljima koje su u prosjeku imale 3,2 malodobna djeteta. Prosječna dob muškaraca iznosila je 38,3, a prosječna dob žena 38,1 godina. U osam bračnih slučajeva žena je bila starija od muža. Riječ je bila o muškarcima i ženama u zreloj dobi od kojih se većina bavila 
poljoprivredom i od kojih se moglo očekivati da će pridonijeti održavanju vojnokrajiškog sustava u gospodarskom i vojnom pogledu.

Za doseljenike u vinkovački kraj nije sačuvan sličan popis, iako postoji poimenični popis glava obitelji s iznosom dugova za pomoć koju su primili prilikom naseljavanja i koju su bili obvezni vratiti Državnoj blagajni. ${ }^{21}$

\section{Smještaj i početni uvjeti za integraciju doseljenika}

Uvjeti u kojima su naseljavani doseljenici iz njemačkih zemalja mijenjali su se tijekom vremena, a ponajviše su ovisili o samoj destinaciji te o tome jesu li naseljavani na komorsko dobro, privatne veleposjede ili u vojnokrajiško područje. Nakon što su u dogovoru s habsburškim vlastima agenti ili drugi posrednici uspjeli pridobiti osobe zainteresirane za preseljenje u jugoistočne dijelove Habsburške Monarhije, slijedile su procedura izdavanja putnih isprava i organizacija puta, ${ }^{22}$ najčešće Dunavom, u pratnji i pod nadzorom državnih službenika. Troškovi migrantskih transporta devedesetih godina 18. stoljeća pokrivali su se iz Državne blagajne, a preko Ratnoga platnog ureda. Dolaskom na odredište u Banat, Srijem ili Slavoniju slijedilo je raspoređivanje imigranta u prazne kuće ili u privremene smještaje dok im se nisu izgradile kuće. Kako bi motivirale doseljenike za ostanak na destinacijama u koje su raspoređeni, vlasti su im obećale vlasništvo nad zemljom, kao što stoji u jednom dokumentu. To je obećanje doseljenike trebalo potaknuti na to da što prije sagrade kuće i da dodijeljeno zemljište što prije pretvore u oranice. Pri izgradnji kuća osigurana im je pomoć domaćeg stanovništva u obliku radne obveze (rabote), primjerice za dovoz potrebne drvene građe, kao i novčana pomoć od dva krajcara na dan za djecu mlađu od dvanaest godina, odnosno od tri krajcara za odrasle po danu kako bi pribavili namirnice neophodne za preživljavanje. Vojne vlasti pretpostavljale su da će doseljenici, nakon što se uvjere da će kuće koje grade jednog dana postati njihovo vlasništvo, upregnuti sve snage $u$ to da ih što prije završe te da će si osigurati dovoljne količine hrane za narednu godinu, tj. da će dodijeljeno im zemljište na vrijeme pretvoriti u oranice i livade (HR-HDA, 430-

21 Bilješka o novčanim i naturalnim dugovima njemačkih doseljenika u Vinkovcima (Vormerkung Uiber sämtliche Geld und Naturall Schulden der deutschen Ansiedler zu Vinkovcze und Liskovacz der ihrer zur Abstattung gesetzter Termine, und vom selben geleisteten Ersatze) (HRHDA, 445-BGP, Satnija u Vinkovcima, knj. 233, god. 1816.-1839.).

22 Proces vrbovanja, transporta i smještaja njemačkih migranta opisao je i na temelju vlastitog iskustva Johann Eimann, imigrant u Bačku koji je tamo radio kao bilježnik, u svom djelu Der Deutsche Kolonist, oder die deutsche Ansiedlung unter Kaiser Joseph dem Zweyten in den Jahren 1783 bis 1787 absonderlich im Königreich Ungarn in dem Bácser Comitat koje je objavljeno u Budimpešti 1822. 
SGK, Opći spisi, kut. 30, 1790-66-84). Doseljenicima se ili davao predujam ili su morali sami potražiti pomoć za nabavu nužnih alata i domaćih životinja. To im se uračunavalo u dug koji su dogovorenom roku morali vratiti.

Za smještaj evangeličkih doseljenika kojima je odobreno podizanje novog naselja kod Pazove, vojne su vlasti dale izraditi plan za izgradnju četrdeset kuća. Kuće su podizane uz pomoć rabote, i to od naboja uz upotrebu drvene građe iz obližnjih šuma. Cijena takve kuće iznosila je između šest i petnaest guldena. ${ }^{23}$ Ubrzo nakon što su bile sagrađene, 1792., devet novopodignutih kuća u Novoj Pazovi bilo je poplavljeno. Generalkomanda je za taj događaj smatrala odgovornima kantonske vlasti jer su, kako je navedeno, trebale predvidjeti takvu nepogodu. Stoga je odlučeno da se uz pomoć graničarske rabote poplavljene kuće premjeste drugamo. Osim toga predloženo je podizanje školske zgrade u Novoj Pazovi. Bogomolja za evangelike nije se smatrala nužnom jer je u obližnjoj Staroj Pazovi novodoseljenim vjernicima na raspolaganju stajao evangelički pastor, iako se vlasti nisu protivile tome da se takva bogomolja izgradi vlastitim sredstvima doseljenika (HR-HDA, 430-SGK, Opći spisi, kut. 32, 1792-66-56). Konkretna materijalna pomoć koju je 1792. država ponudila za 58 njemačkih evangeličkih obitelji u Novoj Pazovi i Novim Banovcima sastojala se od predujma za nabavu alata i stoke u iznosu od $1821 \mathrm{f}$. Ta su sredstva osigurana iz Petrovaradinske kantonske blagajne, a naseljenici su trebali sami izraditi stolove, krevet, klupe i drugi namještaj. Također, Dvorsko ratno vijeće doseljenim je obiteljima odobrilo novčani predujam za nabavu 113 konja, koji su potom kupljeni od Erdődyjeve pukovnije po procijenjenoj vrijednosti (HR-HDA, 430-SGK, Opći spisi, kut. 32, 1792-66-191). Kako bi se što prije osamostalili i stvorili ekonomske uvjete za opstanak, doseljenici su bili oslobođeni poreznih davanja. Ovisno o njihovu ekonomskom napretku i gospodarskim i drugim prilikama u zemlji, često se događalo da su najviše vojne vlasti odobravale produžetak roka na koji su useljenici bili oslobođeni poreznih davanja. Tako su 1800. naseljenici u Novoj Pazovi dobili produljenje tog roka za daljnje tri godine, ali samo oni koji su ispunili očekivanja vlasti - u konkretnom slučaju to se svodilo na pripremu drvene građe za podizanje boljih sjenika (HRHDA, 430-SGK, Opći spisi, kut. 41, 1800-15-7). Nakon što je broj stanovnika u novoosnovanim mjestima dovoljno porastao, javila se potreba za novim zemljišnim posjedima. Tako je novopazovačkim doseljenicima Dvorsko ratno vijeće odobrilo korištenje 184,5 jutara zemlje koja je pripadala pustari

23 Nacrt takve kuće nosi naslov Plan eines Graenz Ansiedlungs Hauses, wie solches in Antrag ist zwischen Pasua und Alt Banovcze auf dem Uiberland zu erbauen (HR-HDA, 430-SGK, Opći spisi, kut. 31, 1791-66-183). 
Tapavica (HR-HDA, 430-SGK, Opći spisi, kut. 47, 1808-R-6/66), a na koju su prema prvotnom planu ti doseljenici trebali biti naseljeni. U posjed dijela tog zemljišta useljenici su došli tek šesnaest godina nakon doseljenja.

Protestantski imigranti u Brodskoj pukovniji dobili su pomoć domaćih graničara u obliku radne i vučne rabote za krčenje šume Liskovac (Ljeskovac) pokraj Vinkovaca kako bi se mogli tamo nastaniti. Tijekom prvih godina nakon useljavanja dobivali su pomoć u hrani od susjednih vojnokrajiških općina. Primjerice 1820. satnijsko je zapovjedništvo u Ivankovu odobrilo pomoć od pedeset vagana pšenice njemačkim doseljenicima u Novom Selu iz općinskog magazina (HR-HDA, 445-BGP, Satnija u Vinkovcima, knj. 206, god. 1820. /21. veljače/), a 1821. za iste se doseljenike iz vojnokrajiških općina Mirkovci, Jankovci, Laze, Slakovci, Privlaka i Otok trebalo osigurati 27 vagana žitarica za sjeme (HR-HDA, 445-BGP, Satnija u Vinkovcima, knj. 206, god. 1821. /10. ožujka/). Pomoć koju su doseljenici primali u obliku graničarske radne rabote i namirnica u naturi zaračunavala im se u dug koji su trebali vraćati nakon isteka razdoblja u kojemu su bili oslobođeni plaćanja poreza. Država je naseljenim obiteljima omogućivala razdoblje poštede kako bi mogli podići svoja gospodarstva. Obitelji naseljene u Novom Selu pored Vinkovaca bile su među onim naseljenicima kojima su vojne vlasti omogućile najpovoljnije uvjete za opstanak u novoj sredini. Te su obitelji bile oslobođene od svih davanja na rok od deset godina, koji je istekao 1829. Zanimljivo je da je Dvorsko ratno vijeće Slavonsku generalkomandu upozorilo da navedene obitelji, unatoč skorom istjecanju roka otplate, ni približno nisu riješile svoje dugove u vezi s naseljavanjem i gradnjom kuća. Ti su dugovi u desetak godina narasli na 21.181 f. 44 kr. (HR-HDA, 430-SGK, Opći spisi, kut. 85, 1828-R-78/36). U istom se izvještaju navode olakotne okolnosti koje su spriječile doseljenike u otplati dugova, ${ }^{24}$ kao i prijedlog Ratnog vijeća da se iznađe način vraćanja duga koji obitelji neće staviti pod prevelik pritisak. Prema planu koji su vojne vlasti sastavile za tu svrhu, njemačke su obitelji trebale biti u mogućnosti vratiti dug u razdoblju od osam godina. U skladu s planom obiteljima bi se nakon žetve ostavio urod potreban za osobnu potrošnju, a ostalo bi se upotrijebilo za vraćanje duga. Isto tako, stoka za koju je procijenjeno da nije nužna za funkcioniranje gospodarstva trebala se oduzeti i prodati - opet u cilju prikupljanja sredstava za povrat duga (HR-HDA, 430-SGK, Opći spisi, kut. 85, 1828-R-78/14).

${ }^{24}$ Kao razlog sporoga ekonomskog napredovanja njemačkih obitelji u Novom Selu navodi se pad vrijednosti nekretnina, čemu je pridonio nepovoljan tečaj papirnatog novca, tako da je njihova vrijednost 1828. iznosila jedva polovinu vrijednosti duga koji su morali vratiti (HR-HDA, 430-SGK, Opći spisi, kut. 85, 1828-R-78/36). 
Premda u izvorima nema podataka o odnosu domaćeg stanovništva prema novopristiglim protestantskim obiteljima, za ilustraciju odnosa prema doseljenicima može poslužiti sadržaj dokumenta iz rujna 1828. koji opisuje uvjete naseljavanja hesenskih katoličkih obitelji u Srijem. Naime vlasti iz Beča dale su upute lokalnim pukovnijskim vlastima u Mitrovici da drže proces naseljavanja tih obitelji pod nadzorom te da im budu pri ruci jer od domaćeg stanovništva naseljenici ne mogu očekivati veliku podršku zato što su često izložene ruganju i zadirkivanju (HR-HDA, 430-SGK, Opći spisi, kut. 85, 1828-R-78/54).

\section{Vjerska i građanska prava protestanata u Slavonskoj vojnoj krajini}

$S$ obzirom na to da je iz perspektive države glavna svrha naseljavanja stanovništva na područje Vojne krajine bila vojno-gospodarska, bilo je važno dovesti one useljenike koji su mogli zadovoljiti te uvjete. Naseljavanje protestanata u Slavonsku vojnu krajinu 1792. i poslije ne bi bilo racionalno sa stajališta države, kao inicijatora i provoditelja tog procesa, ako useljenici ne bi mogli preuzeti obveze graničara. Stalna potreba za popunjavanjem pukovnija ljudstvom nalagala je dovođenje vojno sposobnog stanovništva u područje Vojne krajine. Mali broj protestanata na tom području te zakonska restriktivnost Hrvatskog sabora prema protestantima potaknuli su raspravu o tome trebaju li pripadnici toleriranih religija sudjelovati u vojnokrajiškim vojnim postrojbama. Upravo o tom problemu 1792. piše general topništva Wallis Slavonskoj generalkomandi navodeći da se u njemačke i ugarske pukovnije uzimaju vjernici »pripadnici kršćanskih i toleriranih religija«, pa bi se za vojnokrajiške pukovnije to također trebalo podrazumijevati, i to osobito zbog nedostatka vojno sposobnog osoblja, što se, prema Wallisu, može postići primanjem pripadnika toleriranih religija i porastom broja stanovnika u Vojnoj krajini (HR-HDA, 430-SGK, Opći spisi, kut. 32, 1792-66-38).

Patentom o vjerskoj toleranciji za Ugarsku 1781. nekatoličkim je vjernicima bilo dopušteno obavljanje vlastitih vjerskih obreda. Na području srijemskog dijela Slavonske krajine, u Staroj Pazovi naseljenoj protestantskim Slovacima, od sedamdesetih godina 18. stoljeća djelovao je evangelički pastor koji je nakon naseljavanja njemačkih evangeličkih obitelji u Novu Pazovu i Nove Banovce preuzeo dušobrižničke obveze prema njima. Nakon što su vlasti u Beču 1792. odbile zahtjev za gradnju evangeličke crkve u Novoj Pazovi, dopisom iz Beča upućenom Slavonskoj generalkomandi odobrava se 1820. općinama Nova Pazova i Novi Banovci, i to na njihov zahtjev, vlastiti evangelički pastor. Ta je odluka donesena nakon što je u tim općinama 
evidentirano 117 obitelji i nakon što su općine dostavile dokaze da će svome pastoru, uz crkvena davanja (stolu), moći isplaćivati godišnju plaću od $137 \mathrm{f}$. te osigurati 99 vagana žita, dvanaest hvati ogrjevnog drva i besplatan smještaj (HR-HDA, 430-SGK, Opći spisi, kut. 67, 1820-Q-VIII-17). Dopuštenje za gradnju evangeličke crkve sa zvonikom i sakristijom njemački useljenici u Novoj Pazovi dobili su tek 1842. (HR-HDA, 430-SGK, Opći spisi, kut. 127, 1842-R-56/55). Za njemačke doseljenike u Novom Selu odobren je 1828. evangelički propovjednik. Dvorsko ratno vijeće također je odobrilo da mu se dodijeli zemljište $u$ iznosu cijele baštine, tj. 34 jutra, $i$ to prema istom pravu koje su već uživali protestantski propovjednici u Petrovaradinskoj i Njemačko-banatskoj pukovniji. Evangelički propovjednik bio je oslobođen radnih i poreznih obveza (HR-HDA, 430-SGK, Opći spisi, kut. 84, 1828-R$6 / 2)$.

S obzirom na već spomenutu carsku odredbu iz 1820., koja je potvrđena 1838., o zabrani daljnjeg naseljavanja nekatolika na čitavom teritoriju Vojne krajine i dodjeljivanja prava građanstva toj skupini, valja naglasiti da se ta odredba odnosila samo na nove useljenike, dok su protestantski useljenici koji su na područje Vojne krajine stigli prije te godine mogli zadržati svoje posjede i prava. No odredba je izazivala prijepore, osporavanja i dodatne provjere, osobito $u$ vezi s pravima na rad i sa stjecanjem pojedinih kvalifikacija. Tako je primjerice $u$ dopisu iz 1829. Dvorsko ratno vijeće podsjetilo Slavonsku generalkomandu na odluku o zabrani naseljavanja protestantskih obitelji u Vojnu krajinu i upozorilo da se davanjem majstorskog prava nekatoličkim obrtnicima pomoćnicima (kalfama) zapravo potiče naseljavanje, što je protivno carevoj odluci. Stoga je svim kandidatima za majstorsko pravo u Slavonskoj krajini nametnuta obveza da krsnim listom dokažu kako ne pripadaju kojoj nekatoličkoj vjeri jer im se u protivnome dotično pravo neće moći udijeliti (HR-HDA, 430-SGK, Opći spisi, kut. 87, 1829-QI-78). Primjer sapunarskog pomoćnika Andreasa Diehla iz Petrovardina ${ }^{25}$ svjedoči o tome da su majstorsko pravo unatoč osporavanjima ipak mogli steći oni protestanti koji su mogli dokazati da se njihova obitelj doselila u Slavonsku krajinu prije carske zabrane iz 1820.

O poštovanju zabrane naseljavanja novih protestantskih stanovnika svjedoče i dokumenti iz 1836. u kojima se spominje neuspjeli pokušaj na-

25 Obrtnički pomoćnik A. Diehl u molbi navodi da se njegov otac doselio u Slavonsku krajinu 1818., dakle prije stupanja na snagu zabrane iz 1820., te izražava stav da prema donesenim aktima ima pravo na majstorsko zvanje i pravo građanstva kao i njegov otac. To mu je pravo dodijeljeno, a u obrazloženju se potvrđuje da se njegov otac naselio prije zabrane te da sin samo nastavlja obiteljski posao (HR-HDA, 430-SGK, Opći spisi, kut. 122, 1841-Q17/60). 
seljavanja 64 protestantske obitelji u Boljevce kod Surčina. Te su se obitelji, navodno, još prije dvadeset godina doselile dijelom iz Njemačkog Carstva, a dijelom iz susjednih pokrajina na područje Petrovaradinske pukovnije te su prethodno boravile u različitim mjestima u Granici. Tim obiteljima dakle nisu dopušteni naseljavanje i dodjela zemljišta, za razliku od evangeličkih obitelji u Novoj Pazovi, Novim Banovcima ili Novom Selu (HR-HDA, 430SGK, Opći spisi, kut. 109, 1836-R-134/7; 134/8; 134/10).

Na temelju nekolicine dokumenata u kojima bečke vojne vlasti upozoravaju na zabranu naseljavanja protestanata u Vojnu krajinu može se zaključiti da je na pukovnijskoj razini dolazilo do kršenja ili pokušaja kršenja te carske odredbe. Dvorsko ratno vijeće podsjeća 1843. godine Slavonsku generalkomandu na carevu striktnu odredbu iz 1838. o zabrani »naseljavanja onih koji ispovijedaju evangeličku ili kalvinističku religiju u Hrvatsku ili Slavonsku vojnu krajinu «, kao i na to da se protestantima ne smije dati »pravo zavičajnosti« (Einbürgerung) u Slavonskoj krajini (HR-HDA, 430SGK, Prezidijalni spisi, kut. 16, 1843-38). Iako je to posebna tema za istraživanje u kontekstu građanskih prava protestantskih stanovnika na području Slavonske krajine, valja spomenuti i da su 1843. vlasti u Beču nekim protestantskim obiteljima naložile da se isele iz područja Slavonske krajine. Na to su reagirale evangeličke općine iz Stare i Nove Pazove te Novih Banovaca, a 1843. protestantski pastor Weber iz Nove Pazove i Novih Banovaca na razne adrese šalje pismo o teškoj situaciji protestantskih obitelji u Slavonsko-srijemskoj krajini. Tek carskim Patentom iz 1859. pripadnici protestantskih denominacija stječu pravo useljavanja u sve dijelove Vojne krajine, a njihove općine u svim građanskim poslovima postaju izjednačene s ostalim graničarima (Vaniček, 1875/IV: 412).

\section{ZAKLJUČAK}

U radu su opisane i dokumentirane okolnosti naseljavanja protestantskih obitelji u područje Slavonske vojne krajine od kraja 18. do prve polovine 19. stoljeća. Također su izloženi glavni motivacijski čimbenici tog procesa i uvjeti u kojima se odvijao - u mjeri u kojoj je to razvidno iz pregledanih izvora. Osobita pozornost posvećena je podrijetlu useljenika, njihovim sociodemografskim obilježjima te odnosu vlasti i lokalnog stanovništva prema njima.

Što se tiče općih razloga koji su motivirali političku odluku o poticanju preseljenja stanovništva na jugoistočna područja Habsburške Monarhije, uključujući i prostor Slavonske vojne krajine, kao i odluku onih koji su se 
odlučili na migraciju, istraživanje je potvrdilo navode nekih prethodnih razmatranja o komparativnim prednostima navedenog odredišta: razmjerno maloj gustoći naseljenosti (zbog poznatih povijesnih okolnosti), dostupnosti znatnih zemljišnih površina za obradu, mogućnosti organizacije sustava državne potpore i dobroj prometnoj povezanosti (u prvom redu riječnim putovima), što je zasigurno pogodovalo tijeku i masovnosti migracija.

Ti su motivacijski čimbenici uvjetovali brojne useljeničke valove i u prostor Slavonske vojne krajine tijekom 18. i u prvoj polovini 19. stoljeća. Pritom valja istaknuti dva glavna migracijska pravca: jedan s juga, iz zemalja pod osmanskom i mletačkom vlašću, i drugi sa sjevera, iz srednjoeuropskog prostora, pretežno iz zemalja Svetoga Rimskog Carstva Njemačke Narodnosti i nešto manje iz habsburških zemalja. Migracijski pravac koji je bio u fokusu ovog rada jest onaj iz njemačkih zemalja Dunavom prema jugoistoku Monarhije. Tom je rutom od devedesetih godina 18. stoljeća do dvadesetih godina 19. stoljeća na prostor Slavonske vojne krajine naseljeno (najviše u Novu Pazovu, Nove Banovce i Novo Selo kraj Vinkovaca) stotinjak protestantskih obitelji. Podaci iz dostupnih popisa protestantskih doseljenika iz 1791. pokazuju njihov dobni i spolni sastav, bračni status, zanimanje, mjesto podrijetla te imovinsko-pravnu situaciju, i to s osobitim obzirom na mjesto podrijetla. Sve popisane protestantske obitelji bile su evangeličke, osim jedne koja je pripadala reformiranoj vjeroispovijesti.

Uvjeti pod kojima su naseljavani doseljenici iz njemačkih zemalja mijenjali su se tijekom vremena i bili su različiti ovisno o destinaciji i o tome jesu li naseljavani na komorsko dobro, privatne veleposjede ili u vojnokrajiško područje. Ono što je međutim zajedničko svim migracijskim valovima s odredištem u području Vojne krajine jest njihova vojno-gospodarska svrha: sa stajališta države bilo je važno dovesti one useljenike koji su, uz minimalnu potporu države, mogli samostalno opstati na dodijeljenoj im zemlji, a ujedno se po potrebi uključiti u vojnokrajiške vojne postrojbe. Stalna potreba za popunjavanjem pukovnija ljudstvom nalagala je višekratno dovođenje vojno sposobnog stanovništvo u područje Vojne krajine.

Već sama činjenica naseljavanja protestanata u neko područje pod kontrolom Habsburške Monarhije, zemlje izrazite katoličke orijentacije u unutarnjoj i vanjskoj politici, pokazuje određene "popustljivosti« u provedbi te politike. Mogućnosti naseljavanja protestanata u Vojnu krajinu i stavovi vojnih vlasti u vezi s time mijenjali su se ovisno o zakonskim odredbama i društveno-političkim prilikama. Doseljavanje protestantskih obitelji, ponajprije u srijemski dio Slavonske krajine, odvijalo se nakon odredbi cara Josipa II. iz osamdesetih godina 18. stoljeća koje su bile prožete idejom vjerske 
tolerancije i »liberalnije « iseljeničke politike. Ti se zakonski okviri mijenjaju 1820., kada se carskom odlukom zabranjuje novo naseljavanje protestanata u Vojnu krajinu, koje će prouzročiti narušavanje građanskih i vjerskih prava pripadnicima protestantskih vjeroispovijesti u Vojnoj krajini sve do 1859., kada su protestanti u građanskim poslovima izjednačeni s ostalim graničarima.

Protestantske obitelji, koje su krajem 18. i početkom 19. stoljeća naseljene u Slavonsku vojnu krajinu, smještene su tamo jer u Njemačko-banatskoj krajini, kamo su bile prvobitno upućene, više nije bilo mjesta ni prikladnih uvjeta za njihovo naseljavanje. Uvjeti pod kojima su protestantske obitelji naseljene u Slavonsku krajinu - dodjela zemlje, osiguranje smještaja, pomoć i poticaji u inicijalnoj fazi snalaženja u novoj sredini itd. - ne odudaraju u znatnoj mjeri od onih koje su imali njemački naseljenici katolici. No, s druge strane, nedvojbeno je da ti uvjeti i ostvarivanje građanskih prava nisu bili jednaki onima za katoličko, pa čak ni onima za pravoslavno stanovništvo. Takav »diskriminacijski« odnos bio je posljedica poznatih političkih okolnosti koje su u radu istaknute - prije svega vladarskih odredbi vezanih za protestante u Vojnoj krajini, ali i striktnih i zasebnih zakona Hrvatskog sabora u pogledu prava protestanata, bez obzira na to što Vojna krajina nije bila u jurisdikciji ni Hrvatskoga ni Ugarskoga sabora. Osim toga i izvori i konzultirana literatura podupiru zaključak da ni bečke ni lokalne vojne vlasti nisu bile dosljedne u provedbi zakonskih i upravnih ograničenja nametnutih protestantskim useljenicima, a razlog tome bio je sasvim praktične naravi - potreba za stabilnim odnosima u osjetljivom području Vojne krajine. To je značilo da su se središnje i lokalne vlasti ipak trudile da se i protestantskim useljenicima, kao i onima favoriziranih denominacija, ekonomski olakša opstanak u novoj sredini, barem u inicijalnoj fazi njihova boravka u mjestu preseljenja.

Što se tiče odnosa lokalnog stanovništva prema novonaseljenim obiteljima protestantskih denominacija, ima i pozitivnih i negativnih primjera. $\mathrm{S}$ jedne strane, nastojalo ih se naseliti u odvojenim naseljima ili u blizini mjesta u kojemu su mogli imati pomoć dušobrižnika svoje vjere. Tako su i vojnokrajiške vlasti lakše kontrolirale proces naseljavanja, a novodoseljene obitelji bile su manje izložene porugama i zadirkivanju domaćih graničara. $S$ druge strane, novodoseljenim obiteljima $\mathrm{u}$ inicijalnoj fazi naseljavanja pomoć su pružali domaće stanovništvo i susjedne vojnokrajiške općine. Premda je ta pomoć bila graničarska obveza koju su doseljenici morali nakon određenog razdoblja otplatiti, ona je bila presudna za stvaranje koliko-toliko prihvatljivih uvjeta za njihovo trajno naseljavanje. 


\section{LITERATURA}

Bade, K. J. (2003). Migration in European History. Malden - Oxford - Carlton: Blackwell Publishing, doi: https://doi.org/10.1002/9780470754658

Bader, J. i Jakober, J. (1986). Familien- und Sippenbuch Neudorf bei Vinkovci. Hörsching: Arbeitskreis Donauschäbischer Familienforscher.

Ćelap, L. (1962). Kolonizacija Nemaca u Vojvodini 1790-1792. godine, Zbornik Matice srpske za društvene nauke [Зборник Матице српске за друштвене науке], 32-33: 115124.

Ćirković, S. M. (2008). Srbi među europskim narodima. Zagreb: Golden marketing-Tehnička knjiga.

Demian, J. A. (1806-1807). Darstellung der Oesterreichischen Monarchie nach den neuesten statistischen Beziehungen: Statistische Beschreibung der Militär-Gränze, Sv. I-II. Wien: Rößlsche Buchhandlung.

Eimann, J. (1822). Der Deutsche Kolonist, oder die deutsche Ansiedlung unter Kaiser Joseph dem Zweyten in den Jahren 1783 bis 1787 absonderlich im Königreich Ungarn in dem Bácser Comitat. Pesth: Johann Thomas v. Trattner.

Fata, M. (2014). Migration im kameralistischen Staat Josephs II. Theorie und Praxis der Ansiedlung in Ungarn, Siebenbürgen, Galizien und der Bukowina von 1768 bis 1790. Münster: Aschendorff Verlag.

Gavrilović, S. [Гавриловић С.] (1973). Prilog istoriji Slovaka u Staroj Pazovi 1770-1848. [Прилог историји Словака у Старој Пазови 1770-1848.], Godišnjak Filozofskog fakulteta u Novom Sadu [Годишьькк Филозофског факултета у Новом Саду], 16 (1): 63-68.

Geiger, V. (1991). Nijemci u Hrvatskoj, Migracijske teme, 7 (3-4): 319-334.

Geiger, V. (1998). Nijemci na vlastelinstvu Đakovačke biskupije do 1848./49. godine, Croatica Christiana Periodica, 42, 63-90.

Geiger, V. (2001). Nijemci u Đakovu i Đakovštini. Zagreb: Hrvatski institut za povijest Dom i svijet.

Heka, L. (2013). Hrvatsko-ugarski javnopravni prijepori, Zbornik Pravnog fakulteta u Zagrebu, 63 (5-6): 1257-1292.

Heršak, E. (1993). Panoptikum migracija - Hrvati, hrvatski prostor i Evropa, Migracijske teme, 9 (3-4): 227-302.

Hietzinger, C. B. (1817-1823). Statistik der Militärgränze des österreichischen Kaiserthums, Sv. I, II-1 i II-2. Wien: Verlag bei Carl Gerold.

Hudjetz-Loeber, I. (1989). Heimatbuch Neu-Passua. Die Geschichte eines donauschwäbischen Dörfers. Reutlingen: Heimatausschuss Neu-Passua.

Jambrek, S. (2013). Reformacija u hrvatskim zemljama u europskom kontekstu. Zagreb: Srednja Europa - Biblijski institut.

Kaser, K. (1997). Slobodan seljak i vojnik. Rana krajiška društva (1545-1754), Sv. I; Povojačeno društvo (1754 - 1881), Sv. II. Zagreb: Naprijed.

Krauss, K.-P. (2003). Deutsche Auswanderer in Ungarn. Ansiedlung der Herrschaft Bóly im 18. Jahrhundert. Stuttgart: Franz Steiner Verlag.

Kurelac, M. i Ladić Z. (2005). Hrvatske zemlje početkom 17. stoljeću, u: M. Valentić i L. Čoralić (ur.). Povijest Hrvata od kraja 15. st. do kraja Prvoga svjetskog rata, Knj. 2. Zagreb: Školska knjiga, 105-109. 
Oberkersch, V. (1989). Die Deutschen in Syrmien, Slawonien, Kroatien und Bosnien: Geschichte einer deutschen Volksgruppe in Südosteuropa. Stuttgart.

Oberkersch, V. (1975). Heimatbuch der Deutschen aus Vinkovci und Umgebung. Biberach: Arbeits Gemeinschaft für das Heimatbuch.

Oltmer, J. (2017). Migration. Geschichte und Zukunft der Gegenwart. Darmstadt: Konrad Theiss Verlag.

Roksandić, D. (2004). Etnos, konfesija, tolerancija. Zagreb: SKD »Prosvjeta«.

Schreckeis, H. (1983). Donauschwaben in Kroatien. Historisch-gemographische Untersuchung. Salzburg: Haus der Donauschwaben.

Škiljan, F. i Kralj Vukšić S. (2015). Slovaci u Hrvatskoj u popisima stanovništva između 1880. i 2011. i perspektiva u istraživanju, Človek a spoločnost': Individual and Society, 18 (2): 23-47.

Šišić, F. (1975). Pregled povijesti hrvatskoga naroda. Zagreb: Nakladni zavod MH.

Štefanec, N. (2015). The Adaptable Religious Politics on the Zrinski Estates during the Reformation, u: Z. Blažević, S. Jambrek i N. Štefanec (ur.). The Reformation in the Croatian Historical Lands. Research Results, Challenges, Perspectives. Zagreb - Osijek: Biblijski institut - Filozofski fakultet Sveučilišta u Zagrebu - Visoko evanđeosko teološko učilište, 263-282.

Vaniček, F. (1875). Specialgeschichte der Militärgrenze aus Originalquellen und Quellenwerken geschöpft, Sv. I-IV. Wien: Kaiserlich-königliche Hof- und Staatsdruckerei.

\section{IZVORI}

Hrvatski državni arhiv, Zagreb (HR-HDA)

Fond 430 Slavonska generalkomanda (SGK), serija: Opći spisi, kutije: 13, 16, 27, 29 , $30,31,32,41,42,47,49,67,84,85,87,109,122,127$.

Fond 430 Slavonska generalkomanda (SGK), serija: Prezidijalni spisi, kutija: 16.

Fond 445 Brodska graničarska pukovnija (BGP), serija: Satnija u Vinkovcima, knjige: 206, 233. 


\title{
Settlement of German Protestant Families in the Slavonian Military Frontier in the $18^{\text {th }}$ and Early $19^{\text {th }}$ Centuries
}

\author{
Sanja Lazanin
}

\section{SUMMARY}

The effects of the Reformation in the Military Frontier on the territory of Croatia in the $16^{\text {th }}$ century were weak. There was a Protestant preacher in Karlovac, the main stronghold of the Croatian Military Frontier, who took care of the few members of the Evangelical confession that were mostly officers of Austrian-German descent or were members of the German military garrisons. Bearing in mind the poor representation of confessions arising from the Reformation in the Military Frontier during the $16^{\text {th }}$ and $17^{\text {th }}$ centuries, the author focuses on the gradual change of this practice at the end of the $18^{\text {th }}$ and during the $19^{\text {th }}$ century which took place in the newly created sections of the Military Frontier, from Slavonia to Banat and Transylvania. This area, which became part of the expanded Habsburg military zone after the war with the Ottomans at the end of the $17^{\text {th }}$ century, was the location of great administrative, demographic, ecclesiastical and confessional, and economic changes during the $18^{\text {th }}$ century. The paper focuses on migrations and planned settlement in the SlavoniaSrijem part of the Military Frontier that was carried out in order to maintain a functional Military Frontier system. As part of the intense and numerous migrations in the Slavonia-Srijem regiment areas during the $18^{\text {th }}$ and $19^{\text {th }}$ centuries, the settlement of Protestant families was mainly centred around the Srijem part of the border, especially the Petrovaradin regiment. The number of Protestants in the Military Frontier during the early $19^{\text {th }}$ century, as shown by Hietzinger in his book Statistik der Militärgränze (1817 - 1823), was several times smaller in comparison to the prevailing Catholic and Orthodox population. Taking into account the legal framework and provisions regulating the settlement of Protestants in the Military Frontier, and based on original archive material and the comparison with the published data, the paper presents the course of settling of Protestant families, their origin, socio-demographic characteristics, the conditions of their settlement and the attitude of the authorities and the local population towards them. The paper describes their material circumstances in the new environment, the possibilities of performing religious ceremonies, the attitude of the population of majority confessions towards them, and their civil and religious freedoms at the Slavonian border.

The research for this paper is based on written historical sources from the Slavonian general command which are stored in the Croatian State Archives in Zagreb. This material includes various documents created by the general command administration of the Slavonia-Srijem Military Frontier, which acted as a kind of provincial government in this area. The fund is part of the period from 1701 to 1848 and consists of 162 boxes of documents and 126 books. The analysed material, written exclusively in German language and script, documents the immigration and certain issues from everyday lives of "non-Catholic" families settled at the Slavonian border. It consists mostly of letters from the Aulic War Council to the Slavonian general command or command of the Petrovaradin, Brod and Gradiška regiment and Šajkaš battalion, as well as the canton commands of the same names. This includes orders for the 
main command of the Petrovaradin regiment, tables with the list of immigrants in the Military Frontier, and plans for their accommodation. The conducted research is focused on the decisions and plans of state authorities related to the settlement of Protestant families, but also on the implementation of these plans.

The research suggests that members of confessions derived from the Reformation are referred to with the general term "non-Catholic" or "non-Catholic families" (akatholische/accatholische Familien, acatholische Reichs-Colonisten) in the analysed documents. This term applied exclusively to members of confessional denominations derived from the reformation, both to evangelicals and Calvinists. Occasionally, the documents provide a more precise description of the religion as "evangelical/ Augsburg confessions/religion" (evangelische/augsburgische Konfession/Glaubensbekenntnis/Religion) or "reformed/Helvetic religion" (reformirte/helvetische Religion). Since the 1840s, phrases such as "Protestant families, Protestants" (protestantische Familien, Protestanten) are used for families of reformed denominations in the sources.

It is clear from analysing the material that most of the total immigration to the Croatia-Slavonia Military Frontier occurred up to the middle of the $18^{\text {th }}$ century. However, this process continued after that period as well, particularly in the Slavonia frontier, which was still poorly populated in the middle of the $18^{\text {th }}$ century and provided enough land for new settlers. In the period from 1776 to 1785, over 400 families arrived from the Ottoman and Venetian-Dalmatian regions, and most of them settled in the Petrovaradin regiment. The next wave of settlements occurred during the Austro-Turkish War, from 1788 to 1791, when almost 900 families relocated from Ottoman territory, most of them settling in the area of the Petrovaradin regiment (Kaser, 1997/II: 43-44).

The Reformation did not spread in the Croatia-Slavonia Military Frontier and it did not have a major impact among the population; in fact, the frontiersmen of the Karlovac and Varaždin Generalate fought against the spread of Reformation in the interior countries of the Austria, and also fought in the Thirty Years' War as part of the imperial Catholic forces. The few Protestants who had settled there received, based on the same principle as Orthodox believers, protection for their religious beliefs in the Military Frontier (Hietzinger, 1817/I: 246). Following the adoption of the Patent of Toleration of Joseph II in 1781, the attitude towards the settlement of Protestant families in the Slavonian Military Frontier also changed. Religious freedoms and the relationships among members of different confessions were regulated by various additional provisions. Thus, in 1788, a number of circular letters were published for all the Succession Countries in which the possibility of transitioning from a non-Catholic to Catholic faith is discussed, and details for terms of divorce of non-Catholics are described in cases when one of the partners converts to Catholicism, as well as the conditions for entering into a new marriage.

There were two dominant directions for immigration into the Slavonic Military Frontier. The first direction was the one from the German Empire and the Central European parts of the Habsburg Monarchy to its south-eastern areas, under the supervision of the central authorities in Vienna and the military authorities in the Frontier. The reasons for emigration are typically associated with overpopulation, lack of available land, poor socioeconomic or social status (urban poor, convicts promised amnesty) and unfavourable conditions for entrepreneurial activity, especially craftsmanship. The largest number of German colonists was settled in the German-Banat borderland, i.e. in the German-Banat canton. For example, in 1790, three transports 
of German colonists arrived from Alsace, Lothringia, Swabia, Württemberg and Baden numbering 1921 persons, including Protestant families. Colonists from the Rhineland also settled in the German-Banat canton, as well as the Petrovaradin regiment (Vaniček, 1875/III: 65).

The second migration route, which originated in Ottoman or Venetian territory, brought much more immigrants to the Slavonian Military Frontier. Taking into account only the period of the war with the Ottomans (1788 - 1791), 564 migrant families moved to the area of the Petrovaradin canton.

Although there are no preserved personal data in the sources for all those that the state settled, the transports of immigrants from the German Empire and Hungary to Banat in the early 1790s, which were in part also directed towards Srijem and Slavonia and passed through Petrovaradin, can be analysed based on the preserved tables in the Slavonian General Command fund. Of the six preserved lists for 1790 and 1791, two tables from July 1791 are particularly important sources of demographic and socioeconomic data on evangelical settlers designated for settling on the ley (praedium) near Pazova. One of the tables contains a list of 11 Protestant families, with a total of 63 members, who headed to Petrovaradin without money or material resources to settle in Srijem. Another table contains a list of 8 families, with a total of 45 members, who had some money at their disposal. Based on data from the tables, the age and sex of the immigrants, their marital status, occupation, place of origin and their property/legal situation can be analysed. All these families were Protestant, more precisely Evangelicals, except for one Calvinist family. They were originally from various places in Württemberg. The analysis of the data from the tables revealed that most of them were simple nuclear families with an average of 3.2 underage children. The average age was 38.3 years for men, and 38.1 years for women. These were mature men and women, most of whom worked in agriculture and could be expected to contribute to the maintenance of the border system in economic and military terms.

The conditions under which immigrants from German countries were settled changed over time and depended on the destination and whether they were being settled on the communal state, private estates or the Military Frontier area. However, all migration waves with a destination in the Military Frontier had the same military and economic purpose: from the state's point of view it was important to settle those immigrants who could independently survive on the lands given to them, and if necessary, join the Frontier's military units. The constant need for fresh recruits in the regiments necessitated repeated migrations of military-capable population into the area of the Military Frontier.

KEY WORDS: Protestant families, settlement, Slavonia-Srijem Military Frontier, Germans, $18^{\text {th }}$ and $19^{\text {th }}$ centuries 